Prepared in cooperation with the North Dakota State Water Commission and the International Joint Commission

Characterization of Historical and Stochastically Generated Climate and Streamflow Conditions in the Souris River Basin, United States and Canada

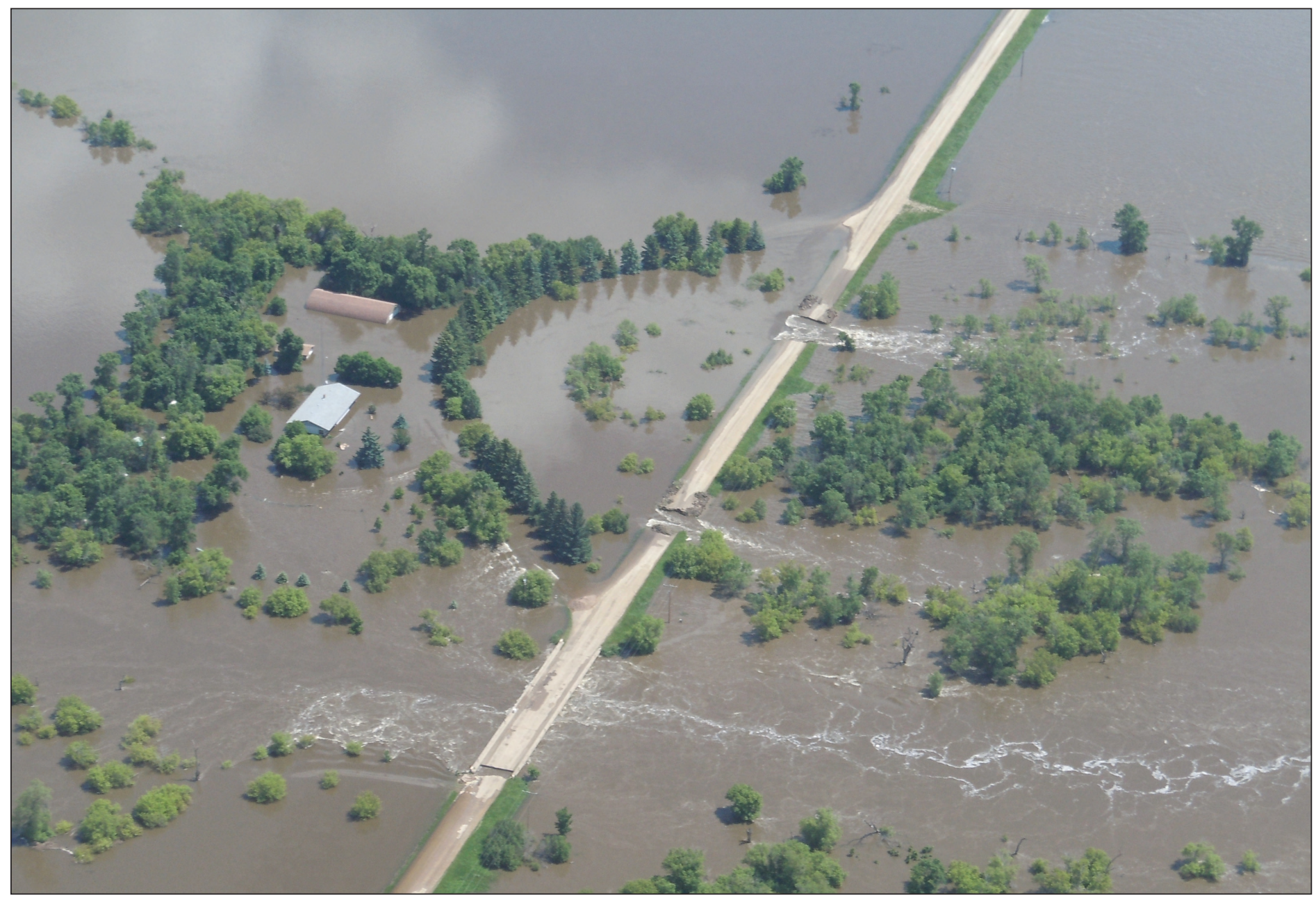

Scientific Investigations Report 2021-5044 
Cover: Photograph showing the Souris River at the U.S. and Canadian border near Sherwood, North Dakota, during flooding on June 23, 2011. Photograph by Joel Galloway, U.S. Geological Survey. 


\section{Characterization of Historical and Stochastically Generated Climate and Streamflow Conditions in the Souris River Basin, United States and Canada}

By Angela Gregory and Joel M. Galloway

Prepared in cooperation with the North Dakota State Water Commission and the International Joint Commission

Scientific Investigations Report 2021-5044 


\section{U.S. Geological Survey, Reston, Virginia: 2021}

For more information on the USGS - the Federal source for science about the Earth, its natural and living resources, natural hazards, and the environment—visit https://www.usgs.gov or call 1-888-ASK-USGS.

For an overview of USGS information products, including maps, imagery, and publications, visit https://store.usgs.gov/.

Any use of trade, firm, or product names is for descriptive purposes only and does not imply endorsement by the U.S. Government.

Although this information product, for the most part, is in the public domain, it also may contain copyrighted materials as noted in the text. Permission to reproduce copyrighted items must be secured from the copyright owner.

Suggested citation:

Gregory, A., and Galloway, J.M., 2021, Characterization of historical and stochastically generated climate and streamflow conditions in the Souris River Basin, United States and Canada: U.S. Geological Survey Scientific Investigations Report 2021-5044, 36 p., https://doi.org/10.3133/sir20215044.

Associated data for this publication:

U.S. Geological Survey, 2014, USGS water data for the Nation: U.S. Geological Survey National Water Information System database, https://doi.org/10.5066/F7P55KJN.

York, B., Gregory, A., and Galloway, J., 2021, Historical and stochastically generated climate and streamflow data for the Souris River Basin, United States and Canada: U.S. Geological Survey data release, https://doi.org/10.5066/ P93AOWFL.

ISSN 2328-0328 (online) 


\section{Acknowledgments}

This report was prepared in cooperation with the North Dakota State Water Commission and International Joint Commission for the International Souris River Plan of Study. This project was part of a much bigger effort to investigate river operations on the International Souris River and required a considerable amount of collaboration between the Canadian Provinces of Saskatchewan and Manitoba, U.S. Federal Government, State agencies, municipalities, and private interest groups. The decision to complete certain analysis provided in this report was based on the focus areas that were decided upon by the International Souris River Study Board. Many thanks are owed to Brett Hultgren (U.S. Army Corps of Engineers), Christopher Korkowski (North Dakota State Water Commission), Chanel Mueller (U.S. Army Corps of Engineers), and Mitchell Weier (U.S. Army Corps of Engineers) for their technical insight on Souris River streamflow and reservoir operations.

We would like to thank Sara Levin (U.S. Geological Survey) and Karen Ryberg (U.S. Geological Survey) for their thorough review of this report. We would like to thank Timothy Fay (International Souris River Board), Simon Papalexiou (University of Saskatchewan), and Gregg Wiche (International Souris River Board) for their input. Many thanks are also due to Skip Vecchia (U.S. Geological Survey), who provided guidance on the statistical analysis completed in support of this project and the provision of background information resulting from his effort on previous projects. 



\section{Contents}

Acknowledgments ……...................................................................................................................

Abstract

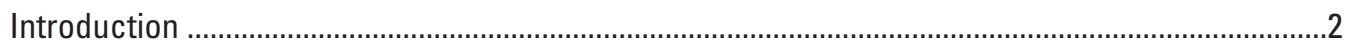

Purpose and Scope ................................................................................................................

Review of Stochastically Generated Natural (Unregulated) and Regulated

Streamflow Models ........................................................................................................

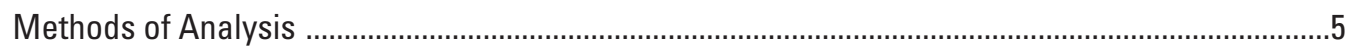

Climate Characterization .............................................................................................

High Streamflow and Drought Characteristics of Natural (Unregulated) Streamflow ............6

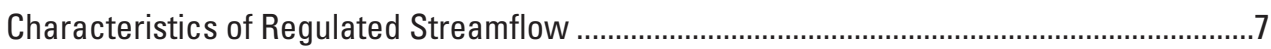

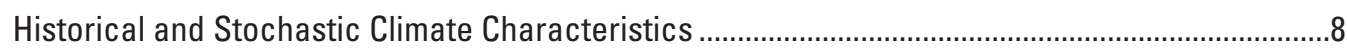

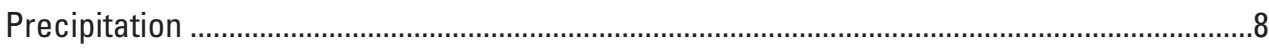

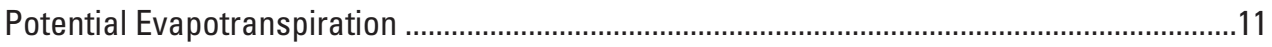

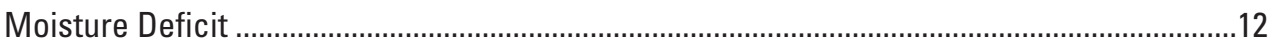

Stochastically Generated Natural (Unregulated) Streamflow Characteristics ...............................15

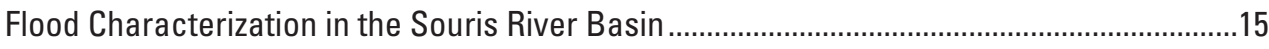

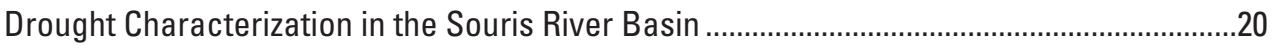

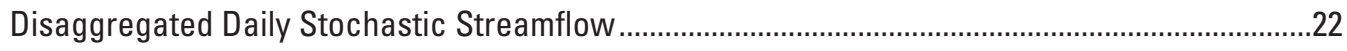

Methods and Data for Generation of Disaggregated Daily Streamflow .................................23

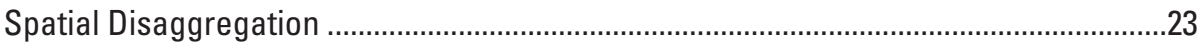

Time-Series Disaggregation of Monthly Streamflow to Daily Streamflow .....................24

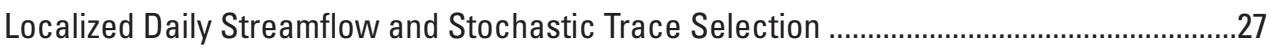

Stochastically Generated Regulated Streamflow and Reservoir Volume Characteristics .............30

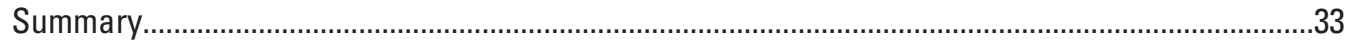

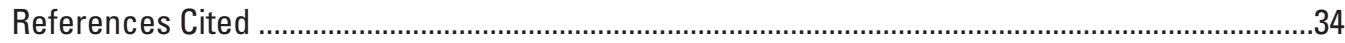

\section{Figures}

1. Map showing the Souris River Basin and locations of reservoirs, weather stations, cities, Canadian streamgages, and U.S. Geological Survey streamgages ........2

2. Map showing Souris River subbasin boundaries, HUC-10 boundaries, HECResSim input sites, stochastic input sites, and rivers ...................................................

3. Graph showing historical annual precipitation for the Souris River Basin, 1912-2011

4. Graph showing monthly precipitation for the Souris River Basin presented with the historical and stochastic monthly maximum and minimum values ..............................

5. Boxplots showing stochastic annual and seasonal precipitation for Rafferty and Boundary Reservoirs, Grant Devine Reservoir, Lake Darling Reservoir, and the Souris River Basin

6. Graph showing annual total potential evapotranspiration for the Souris River Basin, 1912-2011.

7. Graph showing monthly potential evapotranspiration presented with the historical and stochastic minimum and maximum values, for the Souris River Basin, 1912-2011. 
8. Boxplots showing stochastic annual and seasonal potential evapotranspiration for Rafferty and Boundary Reservoirs, Grant Devine Reservoir, Lake Darling Reservoir, and the Souris River Basin

9. Boxplots showing annual and seasonal moisture deficit for Rafferty and Boundary Reservoirs, Grant Devine Reservoir, Lake Darling Reservoir, and the Souris River Basin

10. Graph showing annual peak streamflow from daily data for the Souris River near Sherwood, North Dakota, 1930-2018

11. Graphs showing frequency of stochastic seasonal maximum monthly mean flow volume in spring and summer at sites in Saskatchewan and North Dakota

12. Graphs showing nonexceedance probability for long-term streamflow means at sites in Saskatchewan and North Dakota

13. Graphs showing ratio of 5-, 10-, and 20-year mean streamflow to 1-year mean streamflow by percentile at sites in Saskatchewan and North Dakota.

14. Graphs showing prevalence of historical years with streamflow volume closest to stochastic streamflow.....

15. Graph showing annual historical streamflow volume for the Souris River Basin, 1930-2018

16. Graph showing distribution of annual stochastic streamflow volume for the Souris River Basin

\section{Tables}

1. Annual and seasonal maximum streamflow exceedance probabilities from monthly mean stochastic time series and annual maximum monthly mean streamflow quantiles from reconstructed hydrology at the Souris River below Rafferty Reservoir, Long Creek near Noonan, Moose Mountain Creek near Oxbow, the Souris River near Sherwood, the Des Lacs River at Foxholm, and the Souris River above Minot

2. Annual maximum monthly mean streamflows separated for spring and summer for stochastically generated streamflow at the Souris River below Rafferty Reservoir, Long Creek near Noonan, Moose Mountain Creek near Oxbow, the Souris River near Sherwood, the Des Lacs River at Foxholm, and the Souris River above Minot

3. Co-occurrence of annual maximum monthly mean streamflow for annual, spring, and summer periods

4. Streamflows at the Souris River below Rafferty Reservoir, Long Creek near Noonan, Moose Mountain Creek near Oxbow; the Souris River near Sherwood, the Des Lacs River at Foxholm, and the Souris River above Minot for the 1-, 5-, $10-$, and 20 -year averaging periods

5. Multiplication factors for distribution of stochastic streamflow by basin to local streamflow locations

6. Historical prevalence of wet fall and dry spring on the Souris River below Rafferty Reservoir, Long Creek near Noonan, Moose Mountain Creek near Oxbow, and local flow to Souris River above Lake Darling....

7. Percentile of mean of 30 highest days of spring streamflow as a function of previous November 1 mean standardized precipitation evapotranspiration index for a lag of 3 months and 12 months. 
8. Monthly reservoir inflow volume by exceedance probability to Lake Darling Reservoir....

9. Monthly reservoir storage volume by exceedance probability for Boundary Reservoir, Rafferty Reservoir, Grant Devine Reservoir, and Lake Darling Reservoir ......31

10. Number of occurrences of maximum allowable flood level and full supply level at Rafferty Reservoir, Boundary Reservoir, Grant Devine Reservoir, and Lake Darling Reservoir.....

\section{Conversion Factors}

International System of Units to U.S. customary units

\begin{tabular}{|c|c|c|}
\hline Multiply & By & To obtain \\
\hline \multicolumn{3}{|c|}{ Length } \\
\hline millimeter $(\mathrm{mm})$ & 0.03937 & inch (in.) \\
\hline meter $(\mathrm{m})$ & 3.281 & foot $(\mathrm{ft})$ \\
\hline meter $(\mathrm{m})$ & 1.094 & yard (yd) \\
\hline kilometer $(\mathrm{km})$ & 0.6214 & mile (mi) \\
\hline \multicolumn{3}{|c|}{ Area } \\
\hline square kilometer $\left(\mathrm{km}^{2}\right)$ & 0.3861 & square mile $\left(\mathrm{mi}^{2}\right)$ \\
\hline \multicolumn{3}{|c|}{ Volume } \\
\hline cubic meter $\left(\mathrm{m}^{3}\right)$ & 35.31 & cubic foot $\left(\mathrm{ft}^{3}\right)$ \\
\hline cubic meter $\left(\mathrm{m}^{3}\right)$ & 0.0008107 & acre-foot (acre-ft) \\
\hline cubic decameter $\left(\right.$ dam $\left.^{3}\right)$ & 0.810714 & acre-foot (acre-ft) \\
\hline \multicolumn{3}{|c|}{ Flow rate } \\
\hline cubic meter per second $\left(\mathrm{m}^{3} / \mathrm{s}\right)$ & 70.07 & acre-foot per day (acre-ft/d) \\
\hline cubic meter per second $\left(\mathrm{m}^{3} / \mathrm{s}\right)$ & 35.31 & cubic foot per second $\left(\mathrm{ft}^{3} / \mathrm{s}\right)$ \\
\hline
\end{tabular}

\section{Datum}

Vertical coordinate information is referenced to North American Vertical Datum of 1988 (NAVD 88) for elevations listed in report in the United States and referenced to the Canadian Geodetic Vertical Datum of 1928 (CGVD28) for elevations listed in report in Canada.

Horizontal coordinate information is referenced to North American Datum of 1983 (NAD 83).

Elevation, as used in this report, refers to distance above the vertical datum.

\section{Supplemental Information}

The Canadian water year starts on November 1 and ends on October 31 and is designated by the year in which it ends. 


\section{Abbreviations}

$\begin{array}{ll}\text { FSL } & \text { full supply level } \\ \text { HEC-ResSim } & \text { Hydrologic Engineering Center Reservoir System Simulation } \\ \text { ISRB } & \text { International Souris River Board } \\ \text { ISRSB } & \text { International Souris River Study Board } \\ \text { LOESS } & \text { locally estimated scatterplot smoothing } \\ \text { MAFL } & \text { maximum allowable flood level } \\ \text { PET } & \text { potential evapotranspiration } \\ \text { SPEI } & \text { standardized precipitation evapotranspiration index } \\ \text { USACE } & \text { U.S. Army Corps of Engineers } \\ \text { USGS } & \text { U.S. Geological Survey } \\ \text { WBM } & \text { water balance model } \\ > & \text { greater than } \\ \geq & \text { greater than or equal to } \\ < & \text { less than } \\ \leq & \text { less than or equal to }\end{array}$




\title{
Characterization of Historical and Stochastically Generated Climate and Streamflow Conditions in the Souris River Basin, United States and Canada
}

\author{
By Angela Gregory and Joel M. Galloway
}

\section{Abstract}

The Souris River Basin is a 61,000-square-kilometer basin in the Provinces of Saskatchewan and Manitoba in Canada and the State of North Dakota in the United States. Greater than average snowpack during the winter of 2010-11, along with record-setting rains in May and June 2011, resulted in historically unprecedented flooding in the Souris River Basin. The severity of the 2011 flood led the United States and Canada to request a review of the operating plan for any improvements of reservoir operations and flood control measures in the basin, and the Souris River Basin Task Force was formed. The International Souris River Study Board was then formed in 2017 to carry out the recommendations of the Souris River Basin Task Force laid out in a plan of study. To support the International Souris River Study Board, the U.S. Geological Survey (USGS), in cooperation with the North Dakota State Water Commission and the International Joint Commission, used the previously developed unregulated and regulated streamflow models and data for stochastic streamflow in the Souris River Basin to characterize climate and streamflow and support selection of streamflow traces based on their characterization. Components of the original stochastic hydrology models and their outputs were used in this phase of the study to (1) characterize historical and stochastic climate and streamflow for the Souris River Basin, (2) disaggregate monthly stochastic streamflow spatially and temporally to meet the needs of the U.S. Army Corps of Engineers, Hydrologic Engineering Center, Reservoir System Simulation model for the Souris River Basin, and (3) discuss selection of disaggregated streamflow traces (simulations) using the characteristics of climate and streamflow. A trace is a time series of a stochastic variable such as streamflow, potential evapotranspiration, or precipitation.

To characterize climate conditions, precipitation, potential evapotranspiration (PET), and moisture deficit for the Souris River Basin and individual points at Rafferty, Grant Devine, and Lake Darling Reservoirs were determined annually and seasonally. The annual basin (November 1October 31) precipitation for the 50-percent nonexceedance probability is 452 millimeters ( $\mathrm{mm}$ ). Spring (March-May) is the wettest season, followed by summer (June-August), fall (September-November), and winter (December-February). Annual moisture deficit was largest at Lake Darling Reservoir, followed by Rafferty Reservoir, and then Grant Devine Reservoir.

Annual maximum monthly mean streamflow was determined for the Souris River below Rafferty Reservoir, Saskatchewan (Canadian streamgage 05NB036); Long Creek near Noonan (above Boundary Reservoir), North Dakota (USGS streamgage 05113600); Moose Mountain Creek near Oxbow, Saskatchewan (Canadian streamgage 05ND004); the Souris River near Sherwood, N. Dak. (USGS streamgage 05114000); the Des Lacs River at Foxholm, N. Dak. (USGS streamgage 05116500); and the Souris River above Minot, N. Dak. (USGS streamgage 05117500). When the seasonal maximum monthly mean streamflows are evaluated in contrast to annual maximum monthly mean streamflows separated by their seasonal occurrence, summer months of annual maximum monthly mean streamflows have a higher 50 -percent exceedance probability of streamflow compared to annual maximum monthly mean streamflows that occur in spring, seasonal maximum monthly mean streamflows that occur in spring, and seasonal maximum monthly mean streamflows that occur in summer. When annual maximum monthly mean streamflows in summer are compared to annual maximum monthly mean streamflows in spring, they are consistently higher in streamflow but occur in less than 4.2 percent of years. Evaluation of whether the annual maximum monthly mean streamflows that occur in summer can be described as a separate population from annual maximum monthly mean streamflows that occur in spring was outside the scope of this study, and the summer and spring annual maximum monthly mean streamflows were not tested for statistical differences in mean or variance. Further investigation of seasonal weather patterns that induce flooding could lead to a better understanding of the seasonal differences in flooding.

Long-term hydrologic drought was characterized by evaluating multiyear mean streamflow. Shorter averaging periods have greater streamflow variability than longer periods and hence have a wider range of values. As the averaging period is extended to a longer period, the variability of mean streamflow decreases, and the more extreme streamflow 
volumes seen in shorter averaging periods cannot be sustained. Stochastic streamflow time series were disaggregated spatially and temporally for use in a HEC-ResSim model. The combination of monthly and daily stochastic streamflow data was used to select traces with qualities that could be used to test alternatives focused on water supply, summer flooding, and apportionment.

\section{Introduction}

The Souris River Basin is a 61,000-square-kilometer basin in the Provinces of Saskatchewan and Manitoba in Canada and the State of North Dakota in the United States. The basin topography consists of gently rolling prairie landscape and flat valleys. The main channel of the Souris River is about 700 kilometers $(\mathrm{km})$ in length, originating in southeast Saskatchewan, flowing southeast into North Dakota, and then continuing northward into Manitoba (Kolars and others, 2016). The flow upstream from Minot, North Dakota, is affected by regulation from the Rafferty, Grant Devine, and Boundary Reservoirs in Saskatchewan and Lake Darling Reservoir in North Dakota (fig. 1), which are operated in accordance with an international agreement between Canada and the United States (United Nations, 1989). The basin has a highly variable, semiarid climate characterized by a distinct east-west precipitation gradient with higher amounts in the east and a mean annual potential evapotranspiration (PET) rate that exceeds mean annual precipitation (International Souris River Board, 2009; Ryberg and others, 2016).

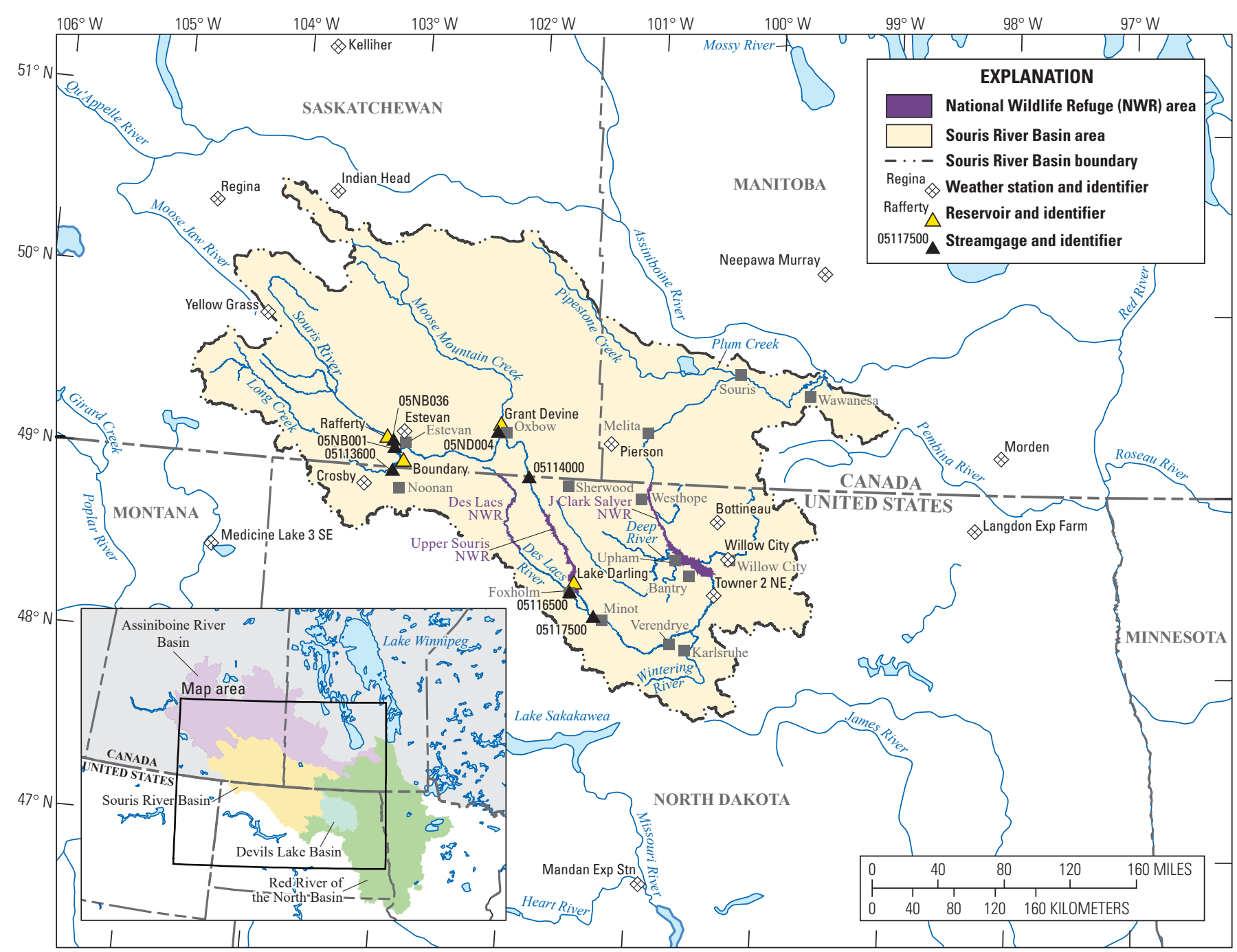

Base from U.S. Geological Survey digital data, 1:2,717,267

Albers Equal-Area Conic projection

Standard parallels $29^{\circ} 30^{\prime} \mathrm{N}$. and $45^{\circ} 30^{\prime} \mathrm{N}$.

Central meridian $96^{\circ} 00^{\prime} \mathrm{W}$.

North American Datum of 1983

Figure 1. The Souris River Basin and locations of reservoirs, weather stations, cities, Canadian streamgages, and U.S. Geological Survey streamgages. 
Before the 1990s, there were two dams on the Souris River: Boundary Reservoir in Saskatchewan, which is operated to cool water from thermal power generation, and Lake Darling Reservoir in North Dakota, which is operated for wildlife management and flood control (fig. 1). Meteorological and tree-ring data indicate a history of severe droughts in the Souris River Basin (Ryberg and others, 2014; Ryberg, 2015), and the potential for periods of extended drought led to the construction of Rafferty Dam and Grant Devine Dam in the 1990s in Saskatchewan (fig. 1). A bi-national agreement was signed in 1989 to provide the basis of flood control and water supply operations for the reservoirs in the Souris River Basin (United Nations, 1989). Because of the transboundary nature of the Souris River Basin, water apportionment and flood forecasting, among other activities, are overseen by the International Souris River Board (ISRB). Board members of the ISRB are volunteers from Federal agencies, State agencies, Provinces, municipalities, and private individuals in Canada and the United States. The board is responsible for ensuring low-flow requirements and apportionment are met and for overseeing flood operations in conjunction with entities identified in the Agreement between the Government of Canada and Government of the United States of America for Water Supply and Flood Control in the Souris River Basin (hereafter referred to as the "1989 international agreement"; United Nations, 1989).

Greater than average snowpack during the winter of 2010-11, preceded by wetter than normal conditions that started in 2008 with an unusually wet fall season in 2010, followed by record-setting rains in May and June 2011, resulted in historically unprecedented flooding in the Souris River Basin (Vining and others, 2013). The severity of the 2011 flood led the United States and Canada to request a review of the operating plan described in annex A of the 1989 international agreement for any improvements of reservoir operations and flood control measures in the basin. The Souris River Basin Task Force was established in 2012 to produce a plan of study and a list of possible methods for evaluating the 1989 international agreement and identifying ways to alleviate flooding issues (International Joint Commission, 2013). The plan of study included measures to review operating rules, improve understanding of flooding, and recommend potential measures to reduce flood risk and protect water supply.

One of the recommendations made by the task force was to develop stochastic (statistically generated) streamflow simulation methods to estimate the exceedance probabilities of future floods and nonexceedance probabilities of future droughts that may be extreme based on the available historical record but less extreme in a much longer historical context. In response to the recommendation, the U.S. Geological Survey (USGS), in cooperation with the North Dakota State Water Commission and the International Joint Commission, developed a stochastic model for simulating precipitation, evapotranspiration, and natural (unregulated) streamflow in the
Souris River Basin (Kolars and others, 2016). The task force also recommended development of a stochastic model that can account for regulation of streamflow for the Souris River Basin upstream from Minot, N. Dak. To address this need, the USGS, in cooperation with the North Dakota State Water Commission and International Joint Commission, built upon the stochastic natural (unregulated) streamflow simulation model by incorporating a reservoir storage/streamflow routing model into the previous work (Kolars and others, 2019).

The International Souris River Study Board (ISRSB) was formed in 2017 to carry out the recommendations of the Souris River Basin Task Force (International Souris River Study Board, 2018). To support the tasks in the plan of study, the USGS, in cooperation with the North Dakota State Water Commission and the International Joint Commission, began a study in 2018 to provide stochastic modeling output and analysis of the stochastic output for use as input for other modeling efforts as part of the ISRSB plan of study to evaluate potential mechanisms for operational improvement in the basin.

Stochastic modeling accounts for the frequency of past climatic events and simulates a series of future realizations of climatic inputs with the same probability distribution as the historical record but with climatic events happening in a variety of orders within each realization. These future realizations of the climatic inputs represent all potential outcomes including multiyear wet or dry periods that are more extreme than any wet or dry periods in the historical period of record.

\section{Purpose and Scope}

The purpose of this report is to describe statistical characteristics of historical and stochastically generated climate variables and streamflow in the Souris River Basin from the headwaters of the Souris River Basin in Saskatchewan through Minot, N. Dak. (fig. 1), and present model results for the disaggregation of stochastically generated streamflow from a monthly time step to a daily time step. The simulated unregulated and regulated streamflow data used in this study were previously published in Kolars and others $(2016,2019)$. The simulated unregulated streamflow disaggregated to a daily time step can be used as daily streamflow input data for the U.S. Army Corps of Engineers (USACE), Hydrologic Engineering Center, Reservoir System Simulation (HECResSim) model (U.S. Army Corps of Engineers, 2013a). The statistical characteristics of the stochastic regulated streamflow analysis can be used to better understand how natural and anthropogenic changes affect the basin. This report presents the results in terms of floods and droughts, as percentiles. The flood analysis is presented for the 50-, 25-, 10-, 5-, and 1-percent exceedance probability. The drought analysis is presented for the 1-, 5-, 10-, 25-, 50-, 75-, 90-, 95-, and 99-percent nonexceedance probability. 


\section{Review of Stochastically Generated Natural (Unregulated) and Regulated Streamflow Models}

Kolars and others (2016) presented a water balance model (WBM) and routing equations for the generation of stochastic streamflow with a 10-day time step for the Souris River Basin. The WBM was developed in R (R Core Team, 2017) based on a model presented by Gray and McCabe (2010). Input to the WBM included monthly time series of temperature, precipitation, and PET. Input to the WBM also included static soils condition data including storage capacity and saturated hydraulic conductivity. The basin was divided into 15 subbasins with outlets at Canadian and USGS streamgages. Climatic inputs were distributed using LOESS, an acronym of locally estimated scatterplot smoothing (Cleveland, 1979; Venables and Ripley, 2002), to estimate values for 1,103 grid cells with a size of $8 \mathrm{~km}$ by $8 \mathrm{~km}$. Runoff generated from each grid cell was then averaged with the other grid cells co-located within 1 of the 15 subbasins (fig. 2) at the monthly time step. The mean subbasin runoff and historical local streamflow were used as input to a linear regression model to numerically characterize any time lags and multiplicative coefficients in the relation. Local streamflow refers to the portion of streamflow contributed to a stream from one smaller basin. The local streamflows were routed through the basin using a translational streamflow model (Kolars and others, 2016). The WBM was calibrated and validated using reconstructed streamflows for the period of 1946-2011 (U.S. Army Corps of Engineers, 2013b).

After the development of the stochastically generated natural streamflow model, the USGS, in cooperation with the North Dakota State Water Commission, developed a regulated model to include the four reservoirs in the basin upstream from Minot, N. Dak., to reflect the application of annex A and annex B reservoir operations rules presented in the

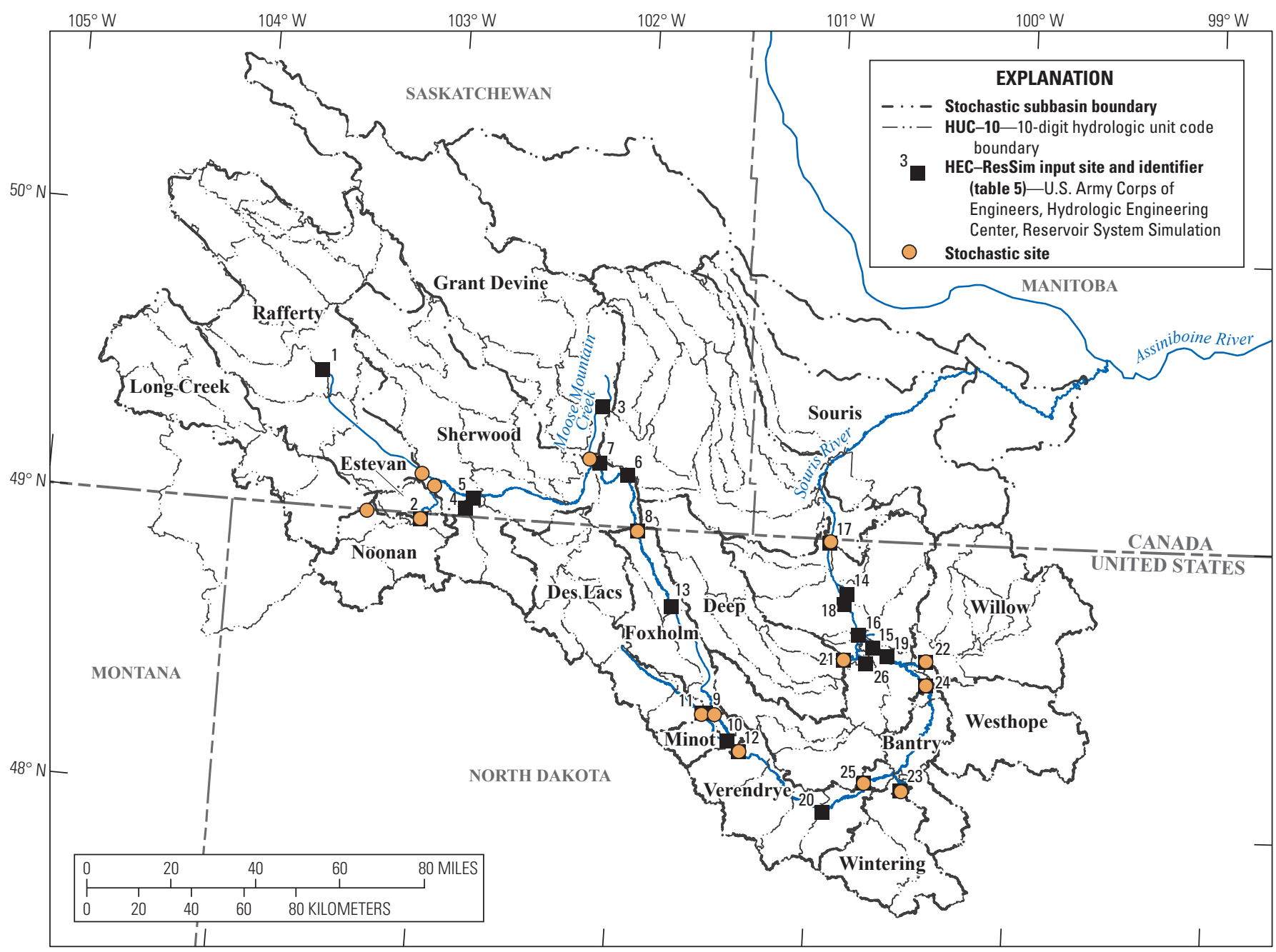

Base from U.S. Geological Survey digital data, 1:1,835,223

Albers Equal-Area Conic projection

Kolars and others, 2016

Standard parallels $29^{\circ} 30^{\prime} \mathrm{N}$. and $45^{\circ} 30^{\prime} \mathrm{N}$

Central meridian $96^{\circ} 00^{\prime} \mathrm{W}$.

North American Datum of 1983

Figure 2. Souris River subbasin boundaries, HUC-10 boundaries, HEC-ResSim input sites, stochastic input sites, and rivers. 
1989 international agreement (Kolars and others, 2019; United Nations, 1989). The purpose of the regulated model was to estimate the probability of reservoir operation events, particularly related to the risk of flooding in the basin. The regulated model was run with the stochastic natural streamflow as input. The regulated model was developed to reflect a simplified version of the operations presented in annex A and annex B (United Nations, 1989).

Annex A was developed for the provision of 100-year flood protection at Minot, N. Dak., and to ensure apportionment is met in the basin according to an International Joint Commission directive in 2007. Each of the four reservoirs have designated water levels that are associated with water supply and flood storage. The results presented in Kolars and others (2019) focused specifically on annual maximum monthly mean streamflows in terms of wet, dry, and transition conditions upstream from Minot, N. Dak., and calibration of reservoir levels and volume.

\section{Methods of Analysis}

Historical and stochastic climate and streamflow data used and generated in previous studies (Kolars and others, 2016; 2019) were characterized in this report. The methods used to analyze the data are presented in this section. All input and output data for models used in this report are available at York and others (2021).

\section{Climate Characterization}

To characterize the climatic conditions in the Souris River Basin, statistical analyses were completed on historical and stochastically generated datasets. Stochastic precipitation, temperature, and PET data used in Kolars and others (2016) were derived using historical data from 16 weather stations within or near the Souris River Basin for the period of 1912-2011. Data were then converted to a gridded product with an $8-\mathrm{km}$ by $8-\mathrm{km}$ grid or 1,103 grid points for the basin using loess described in Venables and Ripley (2002) to derive evenly weighted precipitation and temperature. PET was calculated using the Hamon method (Lu and others, 2005; Huffman and others, 2011) at each grid point, which requires mean temperature, time of year, and latitude to estimate the effect of solar angle on PET. The gridded products were then used to estimate historical basin-averaged and point-specific precipitation and PET at a monthly time step.

Time-series input to the WBM presented in Kolars and others (2016) included precipitation, temperature, and PET. The generation of the stochastic dataset for each time series simulated seasonal and long-term (multiyear) patterns in addition to the random variability associated with each season and variable type. The stochastic dataset consisted of 100 traces (simulations) that are 100 years long with a monthly time step. Like the historical climate dataset, the stochastic climate data are presented in terms of basinwide conditions and conditions at Rafferty Reservoir, Grant Devine Reservoir, and Lake Darling Reservoir. Stochastic precipitation and PET data are presented by Canadian water year (referred to as "annual"), seasonal, and monthly characteristics, and seasons are reflective of the historical climate data. The Canadian water year starts on November 1 and ends on October 31 and is designated by the year in which it ends. Seasons were defined as spring (March through May), summer (June through August), fall (September through November), and winter (December through February).

Stochastic monthly precipitation and PET data were presented as the range of values between their maximum and minimum values. For comparison to the stochastic data, historical data were presented in terms of monthly maximum and minimum values. Quantiles of the stochastic precipitation and PET datasets also were calculated for the 1-, 5-, 10-, 25-, 50-, 75-, 90-, 95-, and 99-percent probability of nonexceedance for the Souris River Basin, Rafferty Reservoir, Grant Devine Reservoir, and Lake Darling Reservoir. Boundary Reservoir was excluded because of its proximity to Rafferty Reservoir. The nonexceedance probability is the probability that the magnitude of an event within the stochastic dataset will be less than or equal to a given value. The Weibull method was used to calculate the nonexceedance probability of events (Helsel and others, 2020).

The moisture deficit (precipitation minus PET) was calculated for each month of the stochastic data. The sum of the moisture deficit was then calculated for each annual time step and for each season, and the quantiles of moisture deficit were obtained at the 1-, 5-, 10-, 25-, 50-, 75-, 90-, 95-, and 99-percent of probability nonexceedance. Calculations for the moisture deficit were completed at Rafferty Reservoir, Grant Devine Reservoir, and Lake Darling Reservoir. Boundary Reservoir was assumed to have the same climatic characteristics as Rafferty Reservoir.

The moisture deficit was also calculated for the period of August 1 to October 31. The moisture deficit was used to calculate the standardized precipitation evapotranspiration index (SPEI) with historical and stochastic meteorological data. The climatic drought index, SPEI (Vicente-Serrano and others, 2010), was selected for use in the ISRSB plan of study to describe antecedent moisture conditions in the Souris River Basin. An analysis of SPEI relative to reservoir inflow was completed for the period of 1979-2016 (Halborg and Muhammad, 2020) by the Water Security Agency in Saskatchewan, Canada, which focused on defining a linear relation between streamflow and SPEI.

The historical calculations in this report included the period of 1946-2013 using the point estimates of moisture deficit at Rafferty, Grant Devine, and Lake Darling Reservoirs. The historical analysis period was limited to 1946-2013 because of the availability of USACE reconstructed hydrology (U.S. Army Corps of Engineers, 2020) with routed streamflow, which is later paired with SPEI to understand the occurrence of wet and dry conditions in the Souris River Basin. SPEI uses 
the monthly moisture deficit to calculate a standardized value for a specified lag period. SPEI is later used to evaluate the distribution of streamflow as it relates to the mean of 3-month and 12-month SPEI.

To calculate the SPEI for the stochastic moisture deficit, the R package, SPEI (Vicente-Serrano and others, 2010), was used. The SPEI package requires input of a monthly time series of moisture deficit and the lag of interest. The lag time step has units of months. The number of months lag is an indication of the number of months that the mean of the moisture deficit should be taken over. For instance, SPEI calculated based on a 3-month lag on November 1 (SPEI calculated with 3 previous months) uses the mean moisture deficit of August through October. The package allows the user to specify the probability distribution and a fitting function to calculate SPEI. The package defaults to the use of the log-logistic distribution with the use of unbiased probability weighted moments (Hosking, 1990) to estimate the log-logistic distribution parameters when not specified, and the defaults were used in this study.

Lags investigated in Halborg and Muhammad (2020) include a 3-month, 6-month, 12-month, and mean of the 3 -month and 12-month lag. The mean of the 3 -month and 12-month lag refers to the individual calculation of 3-month and 12-month calculation and then taking the mean of the two calculations of SPEI. However, further discussion with the technical team of the ISRSB plan of study led to the decision to focus on the mean of the 3-month and 12-month lagged SPEI, and therefore, results of SPEI are limited to the mean of the 3-month and 12-month lagged SPEI values. Calculations of SPEI were completed for Rafferty Reservoir, Boundary Reservoir, Grant Devine Reservoir, and Lake Darling Reservoir using the moisture deficit time series of PET and precipitation that were subset from the gridded meteorological stochastic data discussed in the "Localized Daily Streamflow and Stochastic Trace Selection" section of this report.

Wet and dry periods were classified based on thresholds applied to SPEI values. The occurrence of either dry or wet conditions in one season followed by an opposite condition in the following months, for example, a wet fall followed by a dry spring, is hypothesized to create unique conditions when run through the HEC-ResSim base model, and such unique conditions may indicate the need for a change in operational rules. The fall cutoff is November 1, meaning that meteorological data from August through October can be used to define if the fall may have greater than normal precipitation. Seasons are considered to have greater than normal moisture conditions when they have an SPEI value greater than $(>)$ 0.5. Similarly, an SPEI value less than $(<)-0.5$ is considered to indicate drought (Halborg and Muhammad, 2020). For this study, SPEI is broken into four classes: (1) SPEI is greater than or equal to $(\geq) 0.5$, (2) 0 is less than or equal to $(\leq) \mathrm{SPEI}<0.5$, (3) $-0.5<\mathrm{SPEI}<0$, and (4) SPEI $\leq-0.5$. These classes are used in combination with spring streamflow, and the analysis is discussed in more depth in the "Localized Daily Streamflow and Stochastic Trace Selection" section. The identification of a statistically significant relation between antecedent conditions and streamflow is a goal of the ISRSB. Depending on the degree of uncertainty in an identified relation between antecedent conditions and streamflow, it is possible that relations could be used to make informed decisions about the release of streamflow from reservoirs in Saskatchewan. In the next section, streamflow characteristics are discussed in greater detail before eventually discussing the distribution of streamflow as it relates to SPEI.

\section{High Streamflow and Drought Characteristics of Natural (Unregulated) Streamflow}

High streamflow and drought in the Souris River Basin were characterized using the stochastically generated 10-day natural (unregulated) streamflow time series developed by Kolars and others (2016). Kolars and others (2016) developed a WBM with inputs of stochastically generated precipitation, temperature, and PET. The output from the WBM was 100 streamflow traces at each of the 15 stream sites along the Souris River (fig. 2). Each of the 15 stream sites were associated with a subbasin within the Souris River Basin, and streamflows were only representative of those produced by the subbasin unless routed. The traces were each 100 years long with 36 10-day time steps for each year and maintained spatiotemporal correlation across the basin (Kolars and others, 2016). The 10-day traces were aggregated to a monthly time step assuming that each month consists of three 10-day periods. For this report, the analysis only used 5 sites selected from the 15 streamflow time series presented in Kolars and others (2016) (fig. 1). The primary sites used to characterize inflows to the main reservoirs were the Souris River below Rafferty Reservoir, Saskatchewan (Canadian streamgage 05NB036), and Moose Mountain Creek near Oxbow, Saskatchewan (05ND004; fig. 1) (Government of Canada, 2014). Although the Souris River below Rafferty Reservoir streamflow site name implies that there is regulation in the natural streamflow time series, natural stochastic streamflow time series for this site are assumed to be equal to inflow to Rafferty Reservoir. Other stochastic streamflow time series were from sites on the Long Creek near Noonan, N. Dak. (above Boundary Reservoir; USGS streamgage 05113600); Des Lacs River at Foxholm, N. Dak. (USGS streamgage 05116500); the Souris River near Sherwood, N. Dak. (05114000); and the Souris River above Minot, N. Dak. (05117500; fig. 1) (U.S. Geological Survey, 2014). The evaluation of stochastic monthly streamflow was compared to reconstructed hydrology streamflow for the basin at the same locations for the period of 1946-2013 (U.S. Army Corps of Engineers, 2013b). The reconstructed hydrology streamflow was evaluated in the same way as the stochastic streamflow but was aggregated from a daily time step to a monthly time step for comparison of the two datasets. 
Written communications from the USACE in 2018 indicate that floods in the Souris River Basin are defined as events with a 10-year or greater recurrence interval (10-percent exceedance probability); therefore, use of the term "flood" will be limited to annual maximum monthly mean streamflows with a recurrence interval of 10 years or greater. Annual maximum monthly mean streamflows were identified for each of the 10,000 trace years of stochastic time series at the five selected sites by determining the month within the Canadian water year with the greatest streamflow. The annual maximum monthly mean streamflows were used to identify events associated with the 50-, 25-, 10-, 5-, and 1-percent expected exceedance probability per 100-year period for each site.

Streamflows were also considered for two of four seasons. Annual maximum monthly mean streamflows occurring between March and May are defined as spring events, events occurring between June and August are defined as summer events, and events that did not occur in spring or summer were not evaluated in the report because of data limitations in the fall and winter months. Specifically, not enough historical data exist to make reasonable conjectures about these events. In addition, the sample size of annual maximum monthly mean streamflow in fall and winter is small. Three seasons were previously defined by their unique statistical signals in Kolars and others (2016): November through February, March through June, and July through October. The stochastic streamflow is used in the ISRSB plan of study for evaluating alternatives to annex A (United Nations, 1989); however, from an operations perspective, dam operation decisions often are made based on shorter, predefined seasonal conditions and are, therefore, not defined exactly like those presented in later sections of this report.

The months in which annual maximum monthly mean streamflow occurred were first characterized as happening in the spring or summer seasonal maximum monthly streamflow period and placed into separate bins. The bins of annual maximum monthly mean streamflow were independently characterized by calculating the streamflow associated with the 50 -, 25-, 10-, 5-, and 1-percent exceedance probability of seasonal high streamflows. As a comparison, the maximum monthly mean streamflows from spring and summer were estimated for all 10,000 trace years and plotted against their annual exceedance probability. Literature on the topic of separation of annual peak streamflows discourages separation of annual peak streamflows by season or identification of seasonal peak streamflow as if they are from independent populations (England and others, 2018). For the purposes of this study, however, annual maximum monthly mean streamflows are separated by season, and seasonal maximum monthly mean streamflows are calculated for spring and summer. The application of flood-frequency analysis to separate maximum monthly mean streamflows in the case of this study is of interest because of the potential ramifications of changes to reservoir operations. Operations of the reservoirs in the Souris River Basin are currently (2020) focused on spring events. In the Souris River Basin, annual peak streamflow occurred in summer in 2011 and 2014 in the Souris River Basin and nearby basins, prompting an evaluation of the occurrence of annual maximum monthly mean streamflow in summer months. Considering operation changes to rules for managing summer floods requires that emphasis is placed on evaluation of spring floods and summer floods and not necessarily annual maximum monthly mean streamflow alone. Annual maximum monthly mean streamflow was characterized with consideration to season of occurrence and percentage of exceedance probability of maximum monthly mean streamflow within each season.

Co-occurrence of annual flood events from monthly streamflow was also investigated for the Souris River below Rafferty Reservoir, Moose Mountain Creek near Oxbow, and the Des Lacs River at Foxholm (fig. 1). The Des Lacs River at Foxholm was chosen in this analysis because it has the potential to increase the risk of flooding to the city of Minot. Cooccurrence here refers to the occurrence of a flood that equals or exceeds a flood quantile for one stream occurring at the same time as that of another point in the Souris River Basin. For example, if an annual maximum monthly mean streamflow that equals or is greater than the 10-percent exceedance probability of occurrence annually on the Souris River below Rafferty Reservoir occurs and an event that equals or exceeds the 10-percent exceedance probability of an event on Moose Mountain Creek near Oxbow occurs, then they are interpreted to co-occur. The number of times events cooccurred at a monthly time step was provided for the Souris River below Rafferty Reservoir and Moose Mountain Creek near Oxbow and then extended to the Des Lacs River at Foxholm for the 50-, 25-, 10-, 5-, and 1-percent exceedance probability.

Extended periods of dry hydrologic or drought conditions were also evaluated for the Souris River below Rafferty Reservoir; Long Creek near Noonan, N. Dak. (above Boundary Reservoir; USGS streamgage 05113600); Moose Mountain Creek near Oxbow; the Souris River near Sherwood; the Des Lacs River at Foxholm; and the Souris River above Minot. The mean streamflow was estimated for the 1-year, 5-year, 10-year, and 20-year periods. When a period was greater than 1 year, the number of samples for one trace would be 100 years divided by the number of years averaged. For instance, if a 20-year mean was taken for each trace, there would only be 5 samples per trace, or 500 samples total for the 10,000 trace year period. From the samples, the quantile of occurrence for each event was presented in terms of how many times it might occur in the 10,000 trace year period of stochastically generated streamflow for each site.

\section{Characteristics of Regulated Streamflow}

The Souris River Basin regulated stochastic streamflow model results presented in Kolars and others (2019) in conjunction with the streamflow traces from Kolars and others (2016) were used to describe the characteristics of streamflow and reservoir elevations under regulated conditions. 
Characteristics that were relevant to evaluating operations of the four reservoirs in the Souris River Basin (Boundary, Rafferty, Grant Devine, and Lake Darling Reservoirs) by the ISRSB included (1) monthly regulated inflow volume to Lake Darling Reservoir, (2) monthly mean reservoir volume at each reservoir, (3) the number of times the full supply level (FSL) was surpassed at each reservoir, (4) the number of times the maximum allowable flood level (MAFL) was surpassed at each reservoir, and (5) the relation between inflow volume at Rafferty Reservoir and Grant Devine Reservoir.

Decisions regarding reservoir operations are a function of reservoir volume. The 10-day regulated reservoir volume was averaged for each month of each trace. The 1-, 5-, 10-, 25-, 50-, 75-, 90-, 95-, and 99-percent exceedance probability were then calculated for evaluating characteristics of how the stochastic traces reflect reservoir operations.

Boundary, Rafferty, Grant Devine, and Lake Darling Reservoirs have two distinct operational reservoir elevations: the MAFL is the highest level a reservoir pool is allowed to reach while storing water for flood control where any additional inflow must be released, and the FSL is the maximum elevation that the reservoir pool is allowed to attain when operations are not directed at flood control. The number of occurrences for the two levels was calculated from the 10,000 trace years of stochastic data.

The potential for summer flood events was investigated with several mechanisms. The 50-, 25-, 10-, 5-, and 1-percent exceedance probability events were calculated annually and during summer months to represent annual maximum monthly mean streamflow at Souris River below Rafferty Reservoir, Long Creek near Noonan (above Boundary Reservoir), Moose Mountain Creek near Oxbow, the Des Lacs River at Foxholm, Souris River near Sherwood, and Souris River above Minot (fig. 1). In addition, the number of times the annual maximum monthly mean streamflow occurred during a summer month or spring month was also identified. The maximum month of streamflow was identified for spring of each year in the stochastic dataset, and percentiles of streamflow were calculated like in the annual calculations. This was repeated for the summer months and compared to the annual and spring exceedance probabilities.

\section{Historical and Stochastic Climate Characteristics}

Precipitation and PET drive the production of streamflow in the Souris River Basin. In the last 50 years, the Souris River Basin has experienced increased levels of precipitation and runoff (Ryberg and others, 2014). According to Kolars and others (2016), mean annual precipitation in the basin has changed over time in distinct wet or dry periods. The period of 1912-69 was considered dry, and mean annual precipitation ranged from 365 millimeters $(\mathrm{mm})$ in the southwest part of the basin to $485 \mathrm{~mm}$ in the northeast part of the basin. The period of 1970-2012 was considered wet, and mean annual precipitation ranged from $398 \mathrm{~mm}$ in the southwest part of the basin to $500 \mathrm{~mm}$ in the northeast part of the basin.

The hydroclimatic shifts in the Souris River Basin are not unique to this region. Several quasi-periodic oscillations from wet to dry and dry to wet periods have occurred over the last 1,000 to 2,000 years (Shapley and others, 2005; Vecchia, 2008). A climatic shift from a drier to a wetter climate is known to have occurred around 1970 in the Souris River Basin, leading to an increased risk of flooding (Kolars and others, 2016). A similar shift was detected in neighboring drainage basins such as the Devils Lake Basin and the Red River Basin in the 1980s (Vecchia, 2008). Although most recent focus has been placed on the frequency and magnitude of floods, dry conditions are also a concern. From 1930 to 1940, the Souris River Basin experienced an extended period of drought. Ryberg and others (2014) determined that in the last several hundred years, precipitation trends, developed from a combination of tree-ring and precipitation data in the basin and surrounding region, support the notion that dry periods are a regular part of the climate in the basin and that the 1930s were far from the driest historical conditions.

\section{Precipitation}

The basinwide annual mean precipitation during 1912-2011 (fig. 3) ranged from $243 \mathrm{~mm}$ in 1934 to $659 \mathrm{~mm}$ in 2010. The median historical precipitation for the same period was $460 \mathrm{~mm}$. The stochastic precipitation data are representative of the potential range of cumulative monthly precipitation that might occur in the future. The range of monthly precipitation between the minimum and maximum stochastic precipitation was plotted with the historical maximum and minimum monthly precipitation data for the period of 1912-2011 (fig. 4). In general, the stochastic monthly precipitation fully encapsulated the historical minimum and maximum precipitation. The one exception was May 1917, when the actual minimum monthly precipitation had values smaller than the minimum stochastic monthly precipitation. The reason that May 1917 precipitation was outside of the stochastic range of precipitation has to do with the way that the stochastic precipitation was simulated. Stochastic precipitation time series from Kolars and others (2016) was developed by first simulating seasonal precipitation using historical precipitation from the period of 1912 to 2011 from 16 weather stations (fig. 1). Grouping precipitation into seasonal totals reduces the variability of precipitation in comparison to monthly variability in precipitation. After the seasonal stochastic precipitation was simulated, historical ratios of monthly to seasonal precipitation from one year, for the period of 1946 to 2011, were randomly selected and multiplied by the seasonal precipitation to generate monthly time series of precipitation. The year 1917 was not included in the historical ratio of monthly to seasonal time series values for random sampling. Spring was defined as occurring from March through June in the stochastic 

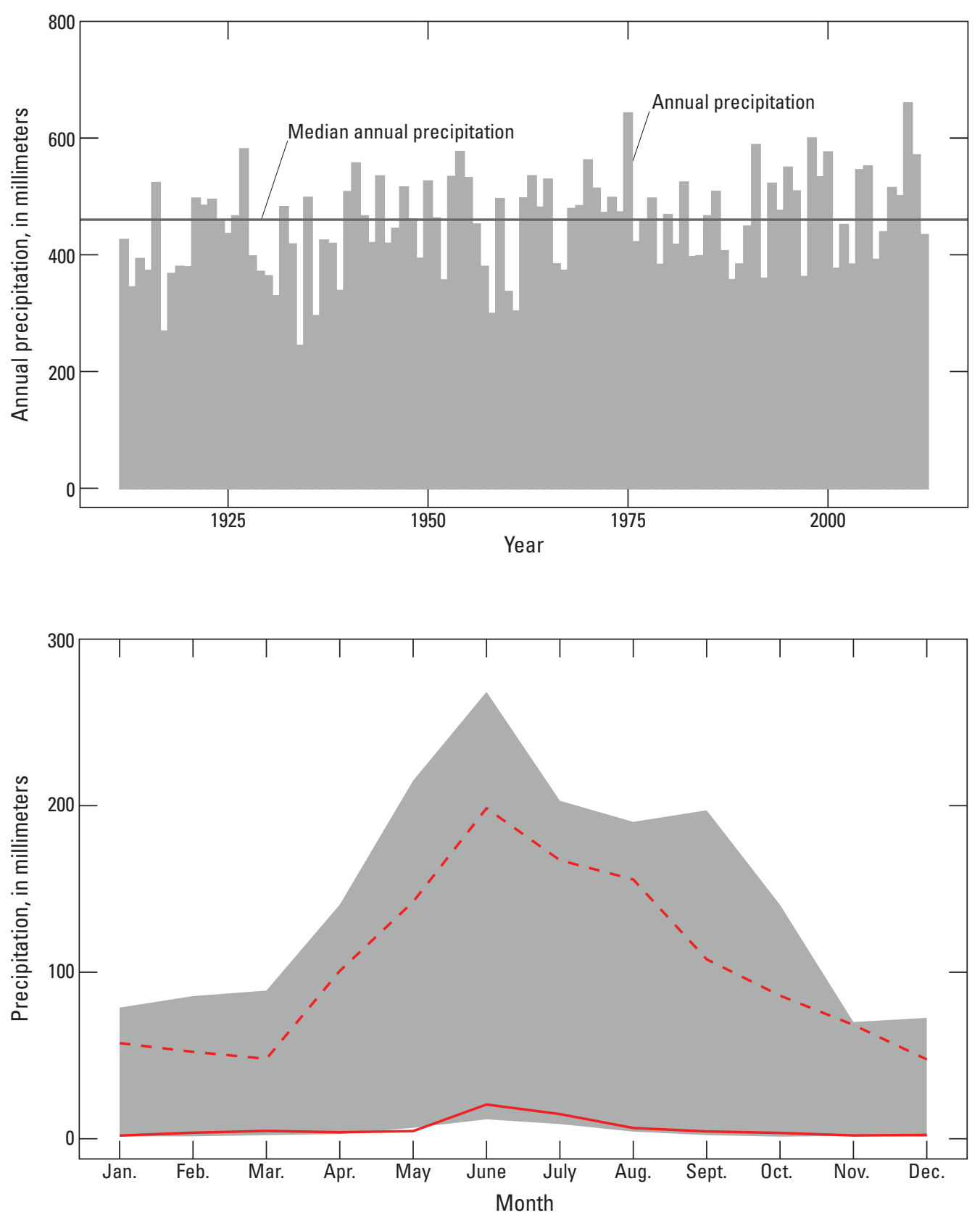

Figure 3. Historical annual precipitation for the Souris River Basin, 1912-2011.

Figure 4. Monthly precipitation for the Souris River Basin presented with the historical (1912-2011) and stochastic monthly maximum and minimum values.

precipitation time series model. In spring of 1917, the total precipitation was not an outlier relative to the spring precipitation totals from 1912 to 2011.

The 50-percent nonexceedance probability of the stochastic precipitation was greatest in summer $(201 \mathrm{~mm})$, followed by spring $(106 \mathrm{~mm})$, fall $(82 \mathrm{~mm})$, and winter $(52 \mathrm{~mm})$ in the Souris River Basin (fig. 5). Rafferty Reservoir and Grant Devine Reservoir are north of Lake Darling Reservoir (fig. 1) and commonly receive more precipitation annually. Seasonal precipitation was used to evaluate spatial differences in precipitation near Rafferty Reservoir, Grant Devine Reservoir, and Lake Darling Reservoir. The 50-percent nonexceedance probability of annual precipitation for Grant Devine Reservoir, Rafferty Reservoir, and Lake Darling Reservoir are 462, 429, and $400 \mathrm{~mm}$, respectively (fig. 5). Grant Devine Reservoir is east of Rafferty Reservoir and tends to receive more precipitation during all seasons regardless of the quantile chosen. All the reservoirs receive more precipitation during the summer months than any other time of year, followed by spring, fall, and then winter. 

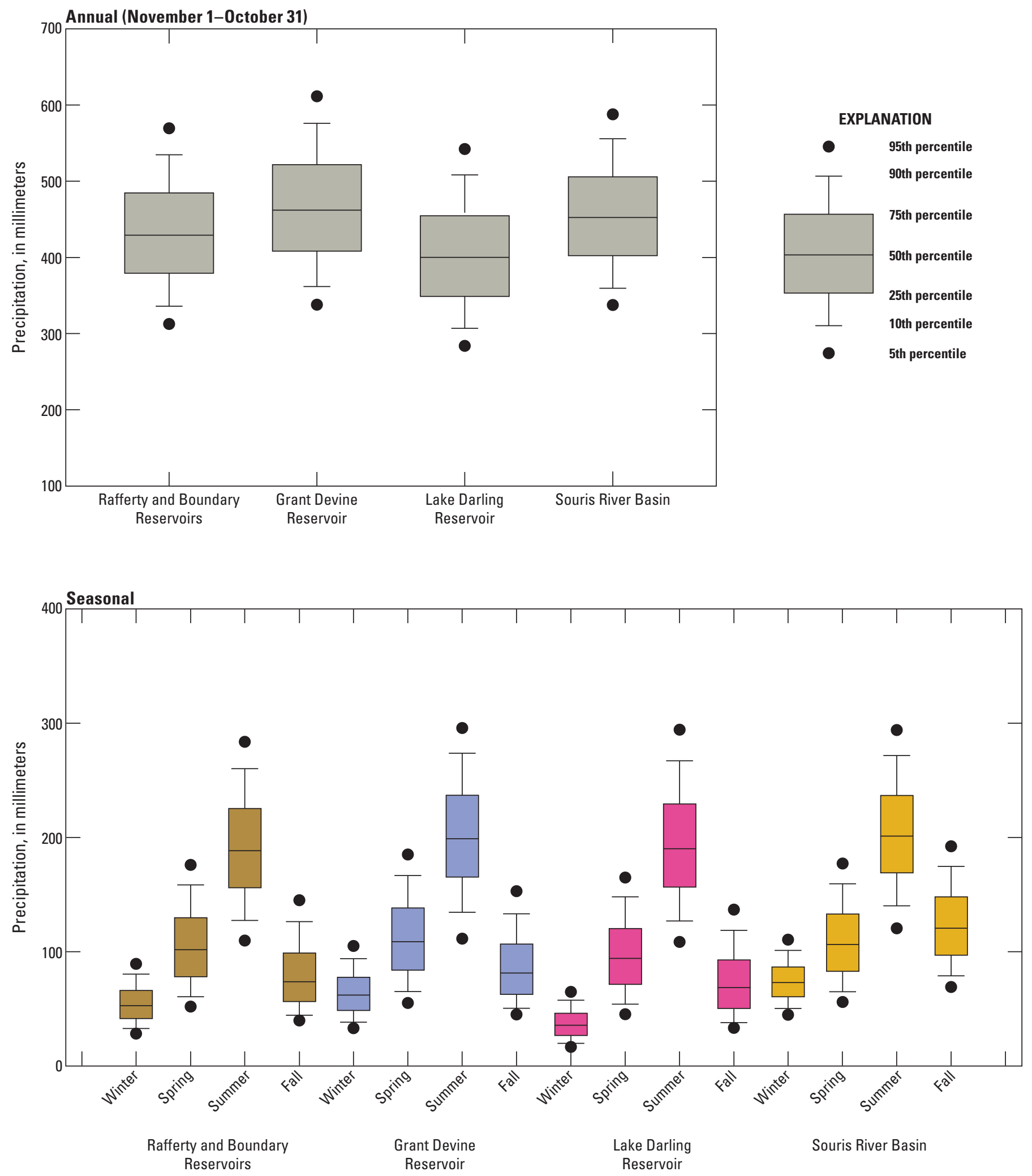

Figure 5. Stochastic annual and seasonal precipitation for Rafferty and Boundary Reservoirs, Grant Devine Reservoir, Lake Darling Reservoir, and the Souris River Basin. 


\section{Potential Evapotranspiration}

Historical mean basin PET was evaluated for the Souris River Basin for the period of 1912-2011 at annual and monthly time steps (figs. 6 and 7). For each month of the year, the annual time series of one month's historical basin mean PET was determined and the results were collated. The maximum and minimum basin mean PET values were then determined from the historical record, and this was repeated for the remaining 11 months; for example, for the month of October, an annual time series of historical basin mean October PET values would be determined, and then the maximum and minimum values would be determined. The mean basin PET for each month was calculated by applying LOESS (Venables and Ripley, 2002) to the weather station PET to estimate PET values at each grid point in the WBM and then taking the mean of the gridded PET values across the basin at each time step. The application of LOESS to the monthly PET from the weather station accounts for the uneven distribution of the weather stations in the basin, and the bias that would occur in the PET time series was averaged from the weather stations alone. Maximum monthly historical PET ranged from $12 \mathrm{~mm}$ in January to $148 \mathrm{~mm}$ in July (fig. 7). Minimum values of PET in January and July were 2 and $87 \mathrm{~mm}$, respectively. The maximum and minimum estimation ranges are important to note because they indicate that the stochastic data are variable enough to contain the historical range of PET. As expected, the greatest amount of PET occurs in the summer months and is lowest during winter. The range of values between the maximum and minimum historical PET lines is indicative of the variability inherent in the data because values of historical PET can fall anywhere between these two lines. Variability is largest during the summer and decreases in the colder months (fig. 7). The change in variability from winter to summer and back is dependent on solar angle, inducing the cyclical nature
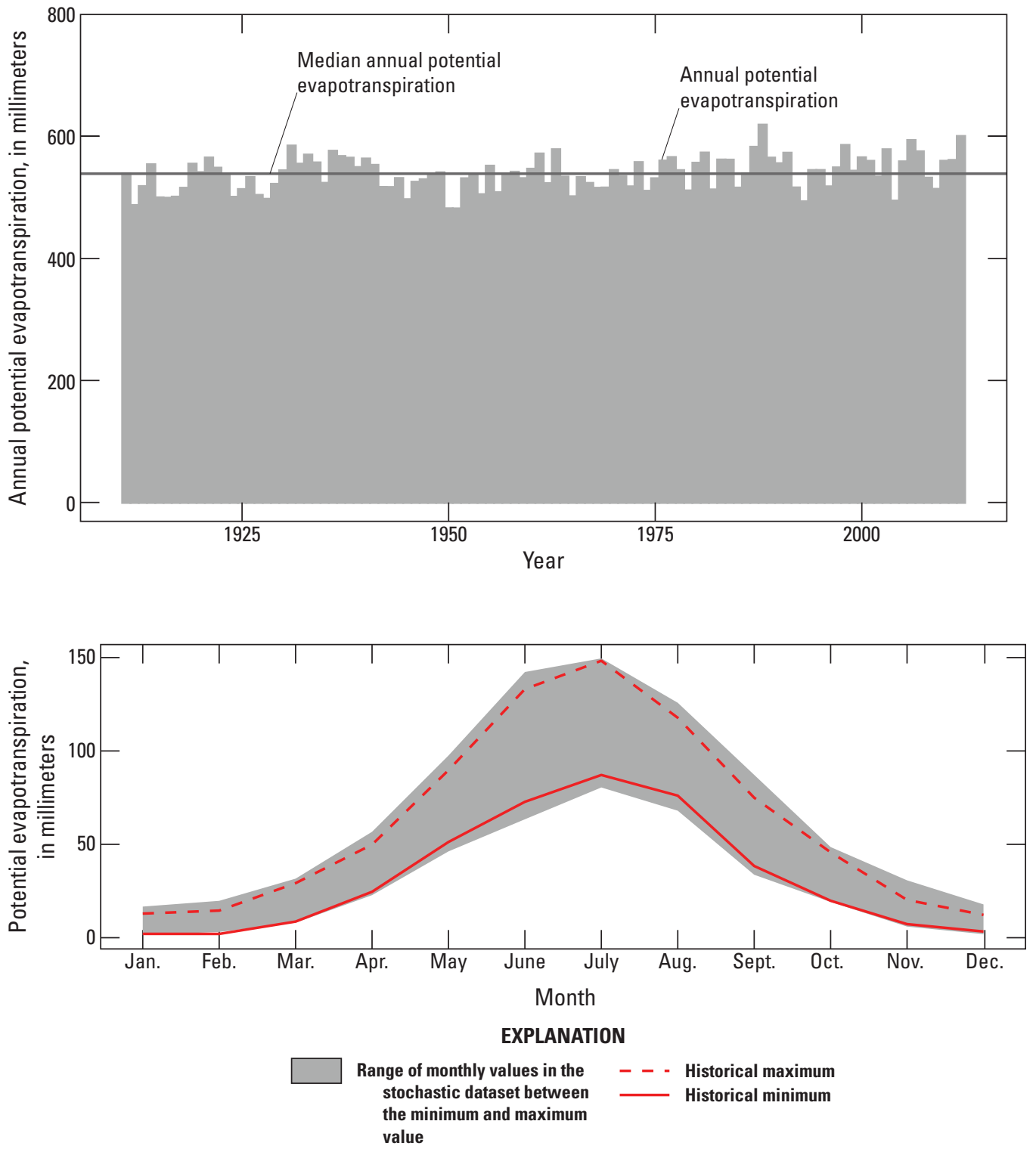

Figure 6. Annual total potential evapotranspiration for the Souris River Basin, 1912-2011.
Figure 7. Monthly potential evapotranspiration presented with the historical and stochastic minimum and maximum values, for the Souris River Basin, 1912-2011. 
of PET with time. In addition, monthly PET is controlled by seasonal climatic patterns and natural variability in weather, and these effects increase as PET increases.

Stochastically generated PET was quantified using mean basin PET across all 10,000 trace years on a monthly time step. Stochastically generated monthly PET values associated with the maximum and minimum PET values were compared with the historical maximum and minimum monthly PET (fig. 7). Historical maximum PET was generally lower than the maximum value of stochastic PET. Historical minimum monthly PET was greater than the minimum stochastic PET except for February 1926, which had a particularly low PET of $2 \mathrm{~mm}$ (fig. 7).

Stochastic PET was calculated for the basin and for Rafferty and Boundary Reservoirs, Grant Devine Reservoir, and Lake Darling Reservoir (fig. 8). The 50-percent nonexceedance probability of annual PET for the stochastic dataset was the lowest at Grant Devine Reservoir $(539 \mathrm{~mm})$ and the highest at Lake Darling Reservoir (552 mm; fig. 8) among the three reservoirs. Grant Devine Reservoir is at the highest latitude and, therefore, would be expected to have the lowest PET, assuming temperature was the same at each of the sites. At all reservoirs, summer accounts for between 55 and 57 percent of the stochastically generated annual PET. Spring accounts for 20 to 24 percent of stochastic PET at all sites, followed by fall, which accounts for 18 to 21 percent, and winter with 3 to 6 percent (fig. 8).

\section{Moisture Deficit}

Moisture deficit was calculated for the basin and at Rafferty and Boundary Reservoirs, Grant Devine Reservoir, and Lake Darling Reservoir (fig. 9). Annual moisture deficit was largest at Lake Darling, followed by Rafferty and
Boundary, and then Grant Devine. The 50-percent nonexceedance probability of annual moisture deficit was $-150 \mathrm{~mm}$ at Lake Darling Reservoir, $-116 \mathrm{~mm}$ at Rafferty and Boundary Reservoirs, and $-75 \mathrm{~mm}$ at Grant Devine Reservoir. Summer had the highest moisture deficit, followed by fall, spring, and winter. Winter was the only season where nearly all quantile moisture deficit values were positive at the three reservoirs, except for the 5- and 10-percent quantiles at Lake Darling Reservoir (fig. 9). Moisture deficit is one indicator of the state of the climate in the basin. Moisture deficit is not solely responsible for the magnitude of runoff events, but it can be used as an indicator of wetter or drier periods relative to streamflow. Continuous periods of large negative moisture deficit may lead to a reduction in spring runoff and base streamflows. Previous studies have determined that the period in which streamflow is highly correlated with the antecedent climate conditions is typically short (less than 2 months), regardless of time of year, and correlation is highest during the summer months and low streamflow periods (Haslinger and others, 2014; Zhu and others, 2016). However, in the Souris River Basin, basinwide annual conditions do not exceed a total moisture deficit of 0 until after the 75-percent nonexceedance probability is surpassed. This is predominantly because of the occurrence of large moisture deficits, particularly in the summer. In addition, PET surpasses actual evapotranspiration and does not account for limitations in actual water storage. Spring and fall moisture deficit are negative until the 50-percent nonexceedance probability is surpassed. The soil conditions in spring in combination with moisture deficit, snow water equivalent in snowpack, and timing of snowmelt are all drivers of spring runoff from snowmelt. Winter moisture deficit is positive except for the 1-percent nonexceedance probability. This holds true for all the reservoirs except Lake Darling Reservoir, which experiences more negative moisture deficit than the other reservoirs. 

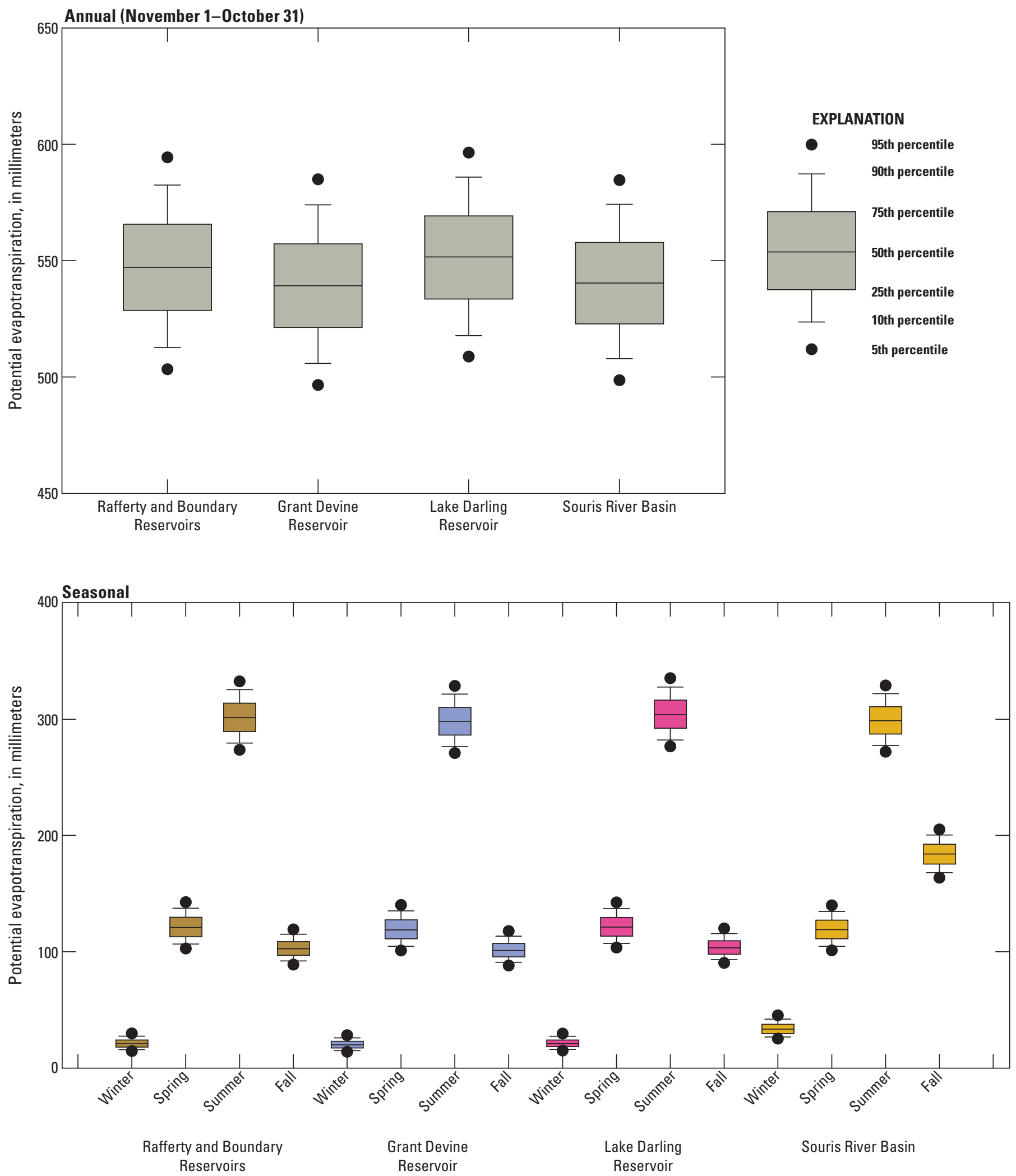

Figure 8. Stochastic annual and seasonal potential evapotranspiration for Rafferty and Boundary Reservoirs, Grant Devine Reservoir, Lake Darling Reservoir, and the Souris River Basin. 

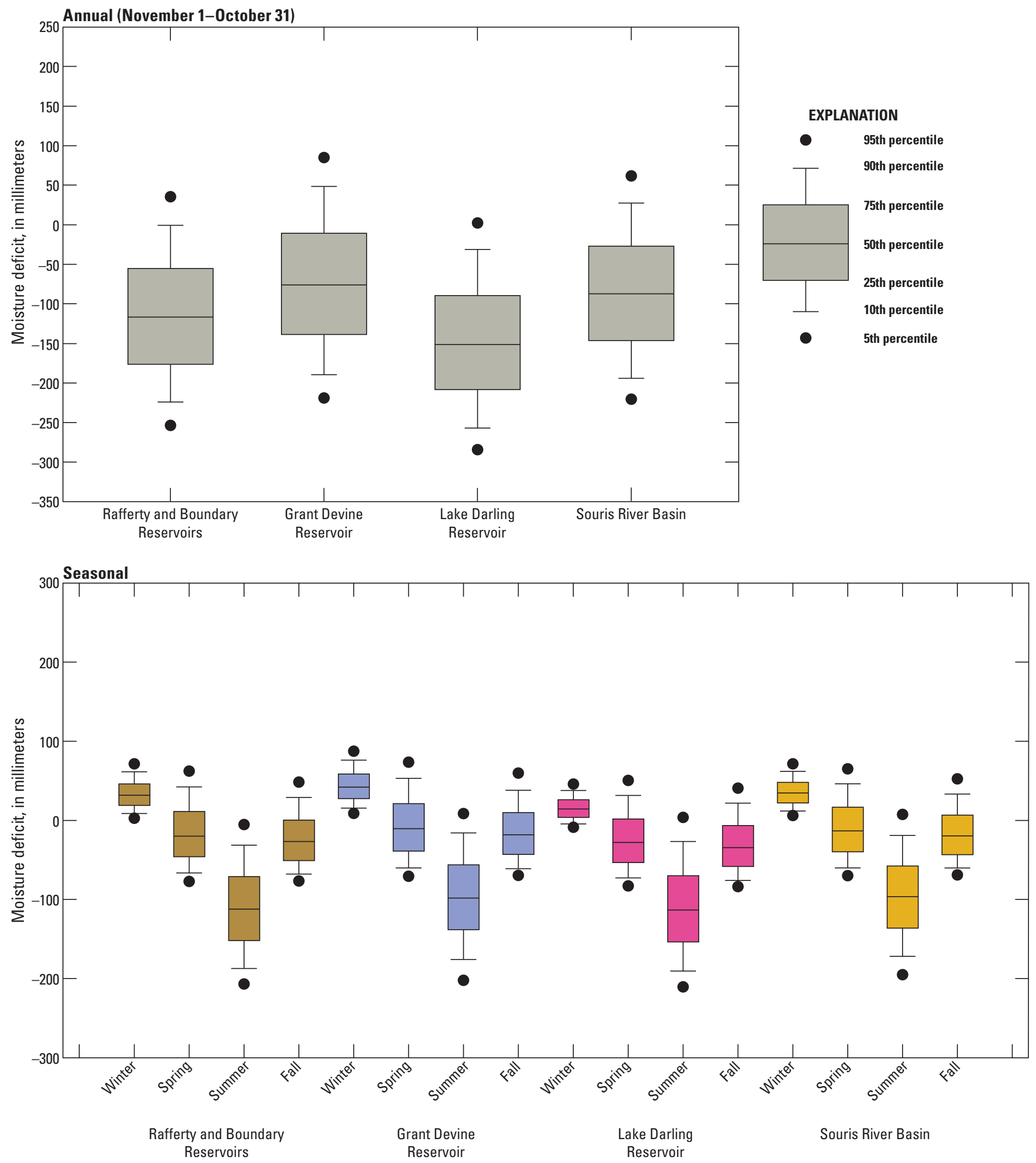

Figure 9. Annual and seasonal moisture deficit for Rafferty and Boundary Reservoirs, Grant Devine Reservoir, Lake Darling Reservoir, and the Souris River Basin. 


\section{Stochastically Generated Natural (Unregulated) Streamflow Characteristics}

Monthly natural (unregulated) streamflow generated stochastically by Kolars and others (2016) provided the foundation for characterizing hydrologic conditions across the Souris River Basin. There were two main focuses in the evaluation of the natural streamflow traces. The first was to evaluate flood occurrence in an unregulated condition annually and to compare spring and summer flood events at a 3-month period and a monthly period. A second interest was in estimating streamflow during extended periods of hydrologic drought.

\section{Flood Characterization in the Souris River Basin}

Many assumptions about reservoir operations in the Souris River Basin were built around peak streamflows occurring only during the spring months with the onset of snowmelt. The snowmelt-generated peaks assumption was based on historical flooding before the 1989 international agreement (United Nations, 1989), and operations were developed based on floods that occurred in 1969, 1974, 1975, 1976, 1979, and 1982 (fig. 10). Recent wet conditions have made the basin susceptible to saturated soil conditions in the spring, summer, and fall. These saturated soil conditions are cause for concern because any flooding can be magnified by a lack of soil moisture storage that might otherwise have been available. Widespread record-setting flooding took place in the Souris River Basin from May to August 2011 (International Joint Commission, 2013). The annual precipitation total was greatest in Canadian water year 2010 (fig. 3) and was in fact wetter than the basin median in 2011 (fig. 3). Under wet conditions, there is the potential for delayed floods with large magnitude and volume. The events leading to the flooding in 2011 prompted the need to evaluate the effects of streamflow in the summer and fall on flooding and reservoir operations.
Annual maximum monthly mean streamflow was estimated for the Souris River below Rafferty Reservoir, Long Creek near Noonan, Moose Mountain Creek near Oxbow, the Souris River near Sherwood, the Des Lacs River at Foxholm, and the Souris River above Minot (fig. 1). Streamflow quantiles from the annual maximum monthly mean streamflow data were computed for the 50-, 25-, 10-, 5-, and 1-percent exceedance probability (table 1). Unrouted annual maximum monthly mean streamflows were the highest for the Souris River below Rafferty Reservoir. Streamflows from the Souris River near Sherwood and the Souris River above Minot were routed through the basin, accumulating streamflow from subbasins and local streamflow upstream from each streamgage (Kolars and others, 2016). If the Souris River did not have structures that regulated its streamflow, streamflow at these locations would be expected to have similar characteristics to the stochastically generated streamflow time series. Unregulated streamflows from the streamgage at Souris River near Sherwood are used in the calculations for apportionment between the United States and Canada (United Nations, 1989). The 2011 maximum mean monthly streamflow into Rafferty Reservoir was $156 \mathrm{~m}^{3} / \mathrm{s}$ and occurred in June according to the reconstructed hydrology (U.S. Army Corps of Engineers, 2020). This surpasses the 1-percent exceedance probability (table 1) streamflow of $105.0 \mathrm{~m}^{3} / \mathrm{s}$ for the Souris River below Rafferty Reservoir within the stochastic streamflow dataset. The 1976 peak annual streamflow was the greatest of the six annual peak streamflow events used in the design of annex A (United Nations, 1989). The 1975 annual peak streamflow occurred in the month of May and was $58 \mathrm{~m}^{3} / \mathrm{s}$ for the Souris River below Rafferty Reservoir (U.S. Army Corps of Engineers, 2020) and falls between the 1- and 5-percent exceedance probability.

Maximum monthly mean streamflows in spring and summer were compared in two ways. First, seasonal maximum monthly mean flow volumes from summer and spring were plotted against their exceedance probability (fig. 11). The seasonal maximum monthly mean flow volumes were calculated by retrieving the maximum monthly mean flow volumes from spring and summer for each of the 10,000 trace years

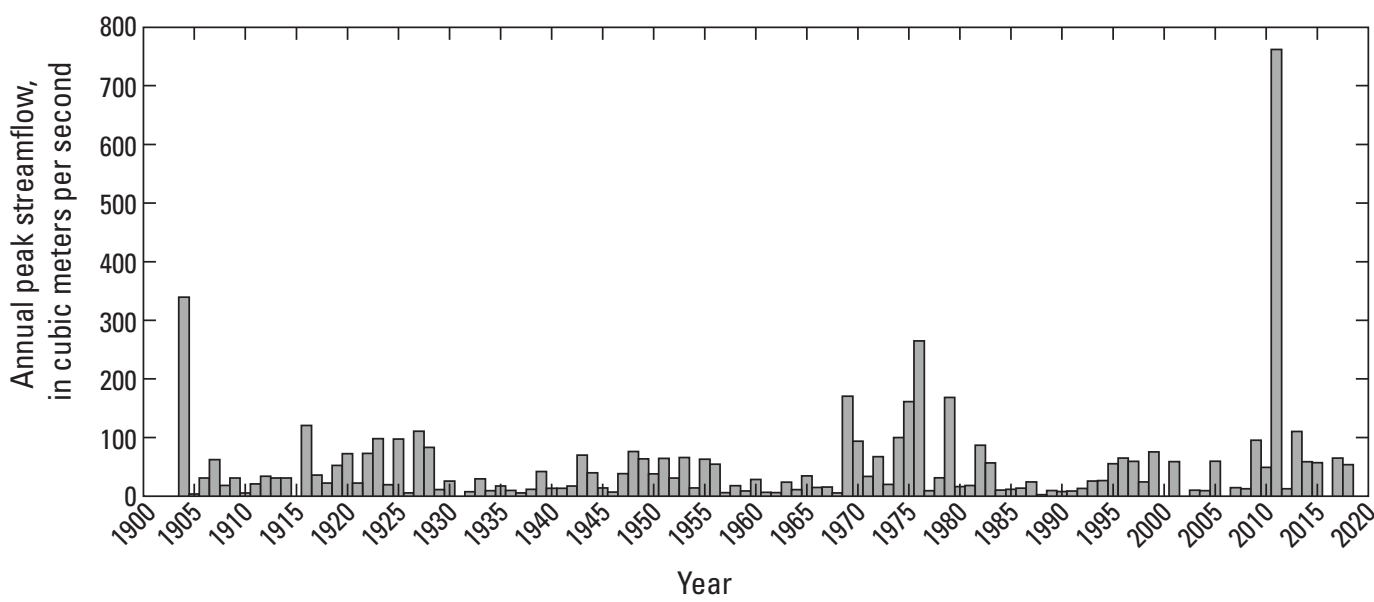

Figure 10. Annual peak streamflow from daily data for the Souris River near Sherwood, North Dakota (U.S. Geological Survey streamgage 05114000; U.S. Geological Survey, 2014), 1930-2018. 
Table 1. Annual and seasonal maximum streamflow exceedance probabilities from monthly mean stochastic time series and annual maximum monthly mean streamflow quantiles from reconstructed hydrology (1946-2013; U.S. Army Corps of Engineers, 2013b) at the Souris River below Rafferty Reservoir, Long Creek near Noonan (above Boundary Reservoir), Moose Mountain Creek near Oxbow, the Souris River near Sherwood, the Des Lacs River at Foxholm, and the Souris River above Minot.

[Annual refers to the Canadian water year, November 1 to October 31; Sask., Saskatchewan; ND, North Dakota; USGS, U.S. Geological Survey]

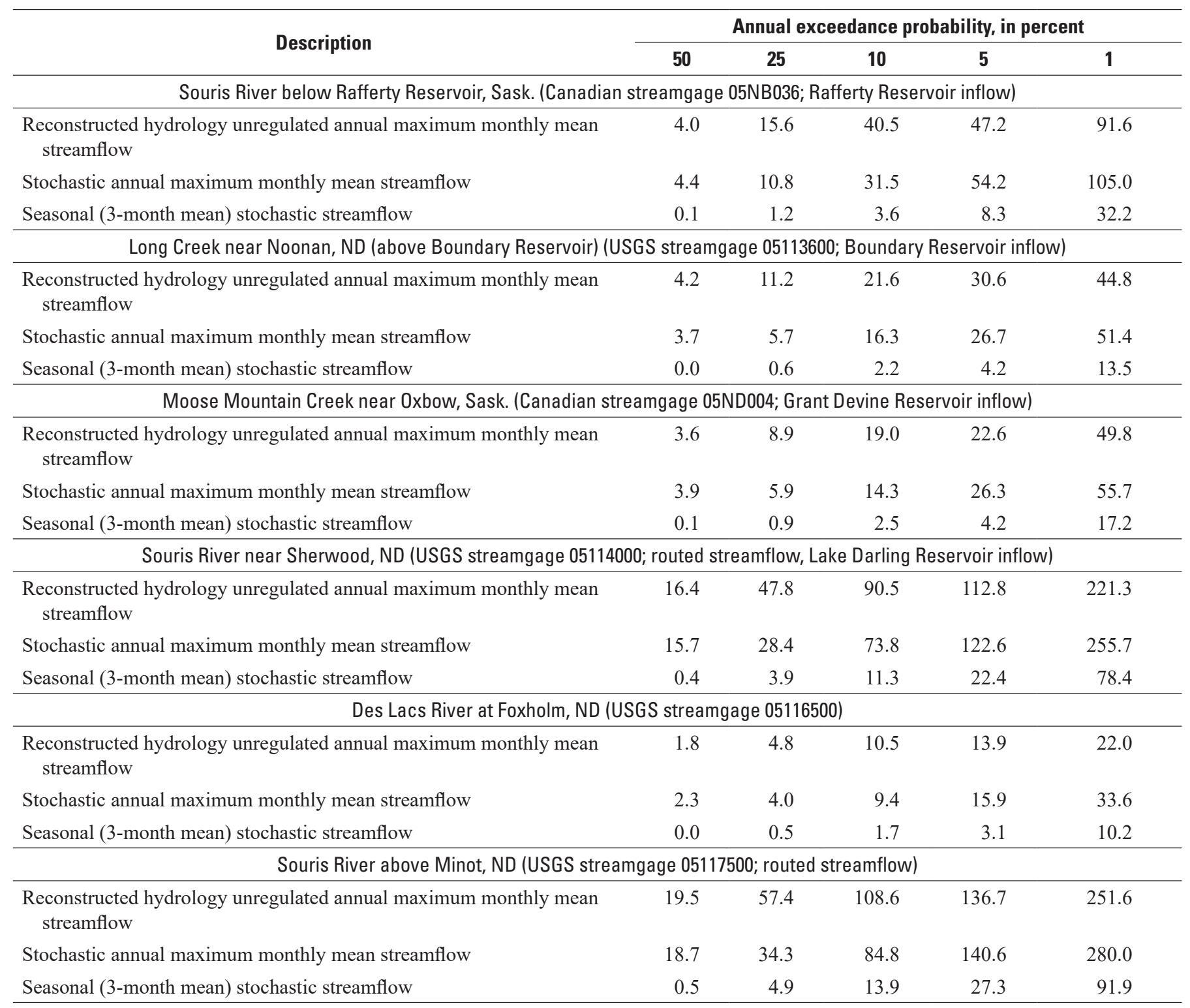

and were assumed to be independent of one another. Summer season maximum monthly mean flow volumes were consistently lower than spring season maximum monthly mean flow volumes. The second comparison separated annual maximum monthly mean streamflows into the season in which they occurred. When the annual maximum monthly mean streamflows are separated by their seasonal occurrence (table 2), summer months of maximum monthly mean streamflow have a higher 50-percent exceedance probability of streamflow compared to annual maximum monthly mean streamflows that occur in spring, spring season maximum monthly mean streamflows that occur in spring, and summer season maximum monthly mean streamflows that occur in summer. When annual maximum monthly mean streamflows in summer are compared to annual maximum monthly mean streamflows in spring, they are consistently higher in streamflow but rare. The number of times an annual maximum monthly mean streamflow event occurred in spring or summer is provided in table 2 . Annual maximum monthly mean streamflows from the 10,000 trace years of stochastically generated streamflows that occur in the summer months only constitute 2.7 percent of 

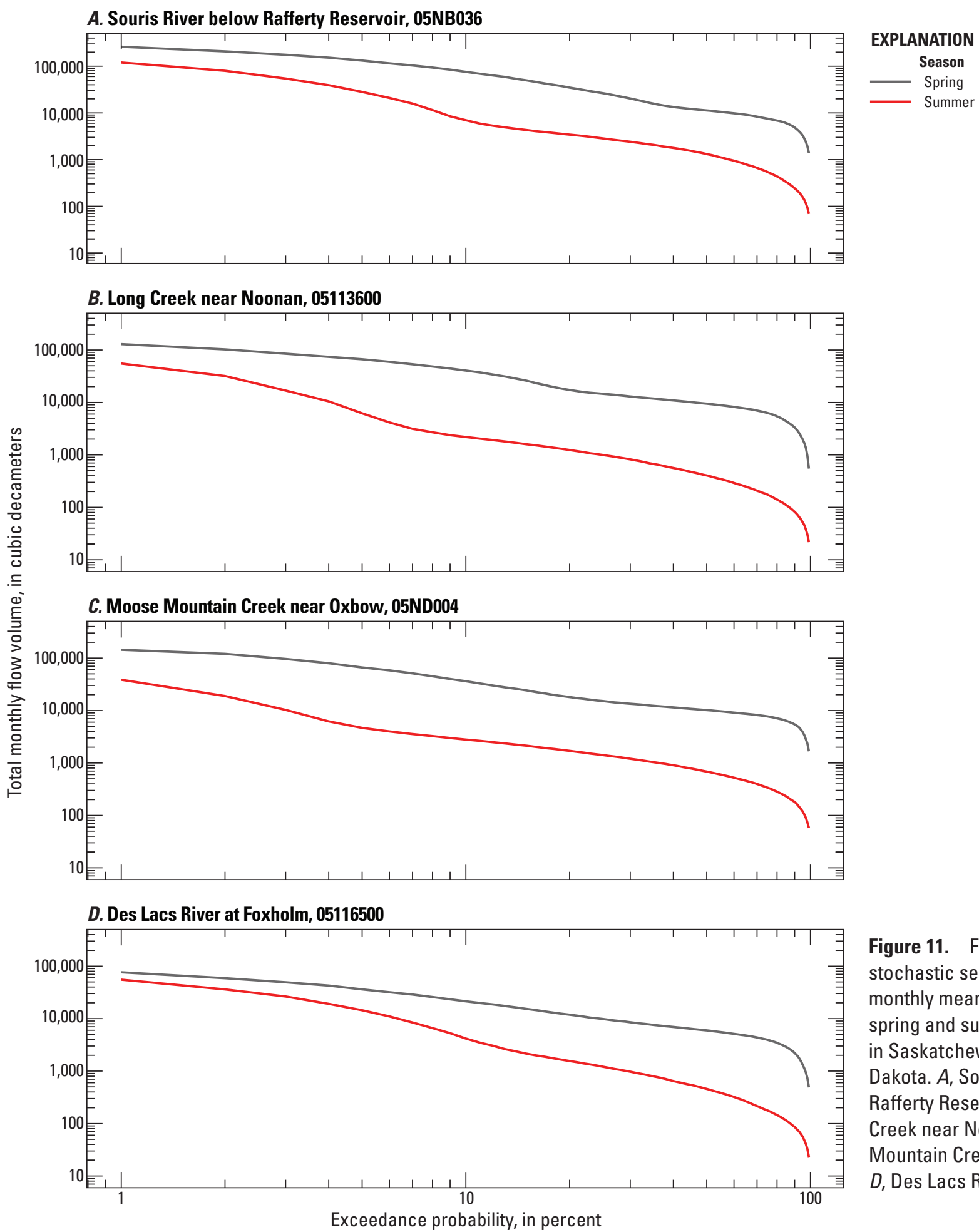

Figure 11. Frequency of stochastic seasonal maximum monthly mean flow volume in spring and summer at sites in Saskatchewan and North Dakota. $A$, Souris River below Rafferty Reservoir; $B$, Long Creek near Noonan; $C$, Moose Mountain Creek near Oxbow; $D$, Des Lacs River at Foxholm.

events at the Souris River below Rafferty Reservoir, 0.6 percent of events at Moose Mountain Creek near Oxbow, and 4.2 percent of events at the Des Lacs River at Foxholm.

The analyses in figure 11 and table 2 show that, in general, spring season maximum monthly mean streamflows are greater than summer season maximum monthly mean streamflows and annual maximum monthly mean streamflows occur more frequently in spring. However, when annual maximum monthly mean streamflows do occur in the summer, they tend to be larger in magnitude than those that occur in the spring.

Although determining the cause of peak streamflow events is beyond the scope of this study, several studies have investigated trends and change points in peak streamflow events using flood-frequency analysis and peaks over 
Table 2. Annual maximum monthly mean streamflows separated for spring and summer for stochastically generated streamflow at the Souris River below Rafferty Reservoir, Long Creek near Noonan (above Boundary Reservoir), Moose Mountain Creek near Oxbow, the Souris River near Sherwood, the Des Lacs River at Foxholm, and the Souris River above Minot.

[\%, percent; Sask., Saskatchewan; spring, March-May; summer, June-August; ND, North Dakota; USGS, U.S. Geological Survey]

\begin{tabular}{|c|c|c|c|c|c|c|}
\hline \multirow{2}{*}{ Season } & \multirow{2}{*}{$\begin{array}{c}\text { Occurrences, in 10,000 } \\
\text { trace years }\end{array}$} & \multicolumn{5}{|c|}{$\begin{array}{l}\text { Seasonal maximum monthly mean streamflow, in cubic meters per } \\
\text { second, for exceedance probability percentages }\end{array}$} \\
\hline & & $50 \%$ & $25 \%$ & $10 \%$ & $5 \%$ & $1 \%$ \\
\hline \multicolumn{7}{|c|}{ Souris River below Rafferty Reservoir, Sask. (Canadian streamgage 05NB036; Rafferty Reservoir inflow) } \\
\hline Spring & 9,574 & 4.4 & 10.3 & 29.6 & 51.6 & 101.0 \\
\hline Summer & 272 & 20.7 & 41.5 & 76.3 & 101.6 & 126.5 \\
\hline \multicolumn{7}{|c|}{ Long Creek near Noonan, ND (above Boundary Reservoir) (USGS streamgage 05113600; Boundary Reservoir inflow) } \\
\hline Spring & 9,156 & 3.8 & 5.8 & 16.6 & 26.8 & 51.4 \\
\hline Summer & 142 & 15.3 & 27.6 & 44.5 & 54.0 & 67.3 \\
\hline \multicolumn{7}{|c|}{ Moose Mountain Creek near Oxbow, Sask. (Canadian streamgage 05ND004; Grant Devine Reservoir inflow) } \\
\hline Spring & 9,780 & 4.0 & 5.9 & 14.2 & 26.1 & 55.6 \\
\hline Summer & 63 & 10.9 & 25.25 & 42.9 & 46.2 & 67.1 \\
\hline \multicolumn{7}{|c|}{ Souris River near Sherwood, ND (USGS streamgage 05114000; routed streamflow, Lake Darling Reservoir inflow) } \\
\hline Spring & 9,565 & 15.8 & 27.7 & 71.9 & 120.1 & 240.8 \\
\hline Summer & 208 & 49.7 & 93.7 & 174.3 & 255.2 & 320.8 \\
\hline \multicolumn{7}{|c|}{ Des Lacs River at Foxholm, ND (USGS streamgage 05116500) } \\
\hline Spring & 9,004 & 2.4 & 3.92 & 8.6 & 14.4 & 30.7 \\
\hline Summer & 420 & 8.5 & 15.6 & 29.2 & 36.2 & 59.1 \\
\hline \multicolumn{7}{|c|}{ Souris River above Minot, ND (USGS streamgage 05117500; routed streamflow) } \\
\hline Spring & 9,467 & 18.8 & 33.5 & 82.6 & 135.5 & 268.0 \\
\hline Summer & 265 & 52.5 & 106.4 & 193.9 & 284.9 & 405.4 \\
\hline
\end{tabular}

threshold. Neri and others (2019) did not find statistically significant proof of increased summer or fall flooding in the Dakotas attributed to precipitation, temperature, or antecedent moisture indices. Research by Ryberg and others (2014), however, indicates that the prevalence of annual peak streamflows in summer and fall are on the rise. Different mechanisms and periods of record were used to investigate the increases in summer streamflow and may be the cause of the different results.

Annual peak floods that occur in summer, like that of the summer of 2011, are likely driven by multiple factors including climate variability, antecedent moisture conditions, precipitation, and temperature (Hoerling and others, 2013; Vining and others, 2013; Ryberg and others, 2014; Mallakpour and Villarini, 2015; Neri and others, 2019). An investigation of the relation between annual peak streamflow and climate drivers by season in Mallakpour and Villarini (2015) determined that the Atlantic Multidecadal Oscillation and, to a lesser extent, the Southern Oscillation Index are positively correlated with increased summer precipitation and flooding at USGS streamgages in North Dakota. In spring, however, the Pacific Decadal Oscillation and Southern Oscillation Index are more prevalent in the establishment of spring floods. The summer floods of 2011 along the Souris River and Red River were attributed to a combination of La Niña conditions between December 2010 and June 2011 along with the cumulation of frozen and saturated ground conditions that exacerbated flooding (Vining and others, 2013). It is not clear whether annual peak floods that occur in summer are a product of the wetter climate that has persisted since the 1970s or something else. Hoerling and others (2013) completed a study of climate conditions in the Missouri River Basin that resulted in the 2011 summer floods and determined that, similar to the Souris River Basin, the runoff efficiency was increased because of greater than mean antecedent soil moisture conditions. Furthermore, the 2011 floods could not be attributed to oceanic moisture or climate patterns that were simulated in a physically based predictive model for the Missouri River Basin (Hoerling and others, 2013).

Neri and others (2019) completed a statistical analysis of the frequency of floods by season associated with peak-over threshold and the covariates precipitation, antecedent moisture, temperature, population density, and agricultural cover at 284 streamgages in the midwestern United States. Peakover threshold is a method used to identify floods that exceed a predefined streamflow threshold (Neri and others, 2019). 
The results of Neri and others (2019) indicated that for spring floods identified using peak-over threshold in North Dakota, there is not a primary mechanism for increased flooding; rather, floods that exceeded the set threshold resulted from the effects of several covariates. In summer, however, floods that exceeded the threshold were more likely to be attributed to a single independent variable. In North Dakota, antecedent moisture conditions were the most prevalent variable associated with increased flooding during summer (Neri and others, 2019).

The spatial extent of annual maximum monthly mean streamflow events can play a role in how reservoir operations are approached. For example, if the headwaters of the Souris River below Rafferty Reservoir experience a 10-year or greater event but Moose Mountain Creek near Oxbow does not experience a 10-year or greater spring runoff event around the same time, the likelihood of negative outcomes resulting from flooding or structural damage is less likely than if a 10 -year event occurs on both rivers at the same time. The larger the area affected by an infrequent rain event or large snowmelt runoff event, the greater the risk of more severe flooding and structural damage. To evaluate how spatial extent plays a role in flood frequency, the probability distribution of annual maximum monthly mean streamflow was compared to the joint probability distribution of flood frequency of two streamflow sites. The role of spatial extent on flood frequency was also evaluated by comparing the probability distribution of annual maximum monthly mean streamflow to the joint probability distributions of flood frequency of three sites. The number of times that a quantile of maximum monthly mean streamflow was exceeded at the Souris River below Rafferty Reservoir and Moose Mountain Creek near Oxbow was determined and then compared to determine which years experienced maximum monthly mean streamflow events equal to or exceeding a given percentile of streamflow together (table 3). For example, the 10-percent exceedance probability of annual maximum monthly mean streamflow event for the Souris River below Rafferty Reservoir was $31.5 \mathrm{~m}^{3} / \mathrm{s}$, and the 10-percent exceedance probability of streamflow at Moose Mountain Creek near Oxbow was $14.3 \mathrm{~m}^{3} / \mathrm{s}$ (table 1). If the annual maximum monthly mean streamflow event at each streamgage equaled or exceeded the 10-percent exceedance probability of annual maximum monthly mean streamflow from their individual probability distributions, the occurrence was counted as co-occurring. One limitation is that this analysis does not include events that result from the same meteorological event but occur in different months because of lag in the travel of the flood wave to a streamgage evaluated in this study. In general, these events happen fewer times than if they were to happen independently. When evaluating the co-occurrence of 10-year events at Souris River below Rafferty Reservoir and Moose Mountain Creek near Oxbow, the expected co-occurrence of a 10-year event was reduced to an event that happens between seven and eight times during a 100 -year period and the co-occurrence of a 50-year event is expected to happen one time per 100 years.

The analysis was extended further to include the Des Lacs River at Foxholm streamflow. With the inclusion of the Des Lacs River at Foxholm, the co-occurrence of a 10-year event is further reduced to four to five times in a 100-year period. The larger the area affected by such events, the less likely they are to occur. Because this dataset is a stochastic time series, it is uncertain whether these events are outliers or if they have the potential to occur a handful of times in a 10,000 trace year period.

Table 3. Co-occurrence of annual maximum monthly mean streamflow for annual, spring, and summer periods.

[Annual refers to the Canadian water year, November 1 to October 31; Souris River below Rafferty Reservoir refers to Canadian streamgage 05NB036; Moose Mountain Creek near Oxbow refers to Canadian streamgage 05ND004; Des Lacs River at Foxholm refers to U.S. Geological Survey streamgage 05116500]

\begin{tabular}{|c|c|c|c|c|c|}
\hline \multirow[t]{2}{*}{ Description } & \multicolumn{5}{|c|}{$\begin{array}{l}\text { Exceedance probability, in percent, used to identify streamflow threshold } \\
\text { for each location }\end{array}$} \\
\hline & 50 & 25 & 10 & 5 & 1 \\
\hline \multicolumn{6}{|c|}{ Souris River below Rafferty Reservoir and Moose Mountain Creek near Oxbow } \\
\hline Regardless of season & 4,013 & 1,977 & 758 & 353 & 60 \\
\hline Spring & 3,965 & 1,935 & 739 & 342 & 59 \\
\hline Summer & 44 & 38 & 17 & 11 & 1 \\
\hline \multicolumn{6}{|c|}{ Souris River below Rafferty Reservoir, Moose Mountain Creek near Oxbow, and the Des Lacs River at Foxholm } \\
\hline Regardless of season & 2,929 & 1,393 & 460 & 196 & 24 \\
\hline Spring & 2,899 & 1,369 & 446 & 189 & 23 \\
\hline Summer & 29 & 24 & 14 & 9 & 1 \\
\hline
\end{tabular}




\section{Drought Characterization in the Souris River Basin}

A 1-year, 5-year, 10-year, and 20-year mean of monthly streamflow volume was calculated for each of the 100 traces at the Souris River below Rafferty Reservoir, Long Creek near Noonan (above Boundary Reservoir), Moose Mountain Creek near Oxbow, the Souris River near Sherwood, the Des Lacs River at Foxholm, and the Souris River above Minot. Streamflow quantiles were computed for each of the averaging periods. The long-term mean streamflow volumes were used to characterize long-term streamflow in the Souris River Basin (fig. 12). Shorter periods of mean streamflow volume are characterized by greater variability than longer periods of mean streamflow and hence include lower mean streamflow in the lowest percentiles and higher mean streamflow in the highest percentiles. As the averaging period is extended to a longer period, the variability of mean streamflow decreases, and the more extreme variability of mean streamflow volume seen in shorter averaging periods cannot be sustained.
One feature seen in figure 12 is the crossover of longterm mean streamflow volume lines as a function of quantile. As the percentage chance of nonexceedance increases, the mean streamflow volume curves switch order, and this occurs between 75- and 90-percent nonexceedance probability. As the nonexceedance probability decreases below 75 percent, longer period means have the highest mean streamflow volumes and shorter periods have the lowest mean streamflow volumes. A summary of long-term mean streamflow is provided in table 4 . The sample sizes for each of the averaging periods decreased as the averaging period increased. The number of samples per averaging period are noted in the left-hand column of table 4. The averaging period is also presented in the left-hand column. The 50-percent nonexceedance probability of stochastically generated streamflow for the 1-year mean streamflow for the Souris River near Sherwood was $2.42 \mathrm{~m}^{3} / \mathrm{s}$ and increased to $4.73 \mathrm{~m}^{3} / \mathrm{s}$ for the 20 -year mean (table 4 ). The occurrence of a 20 -year mean streamflow less than or equal to $2.42 \mathrm{~m}^{3} / \mathrm{s}$ is expected to occur between 5 and 1 percent of 20 -year periods for the Souris River near Sherwood (table 4). Long Creek near Noonan (above Boundary Reservoir) has lower mean streamflow than either the Souris River below Rafferty Reservoir or Moose Mountain Creek near Oxbow.

B. Long Creek near Noonan, 05113600
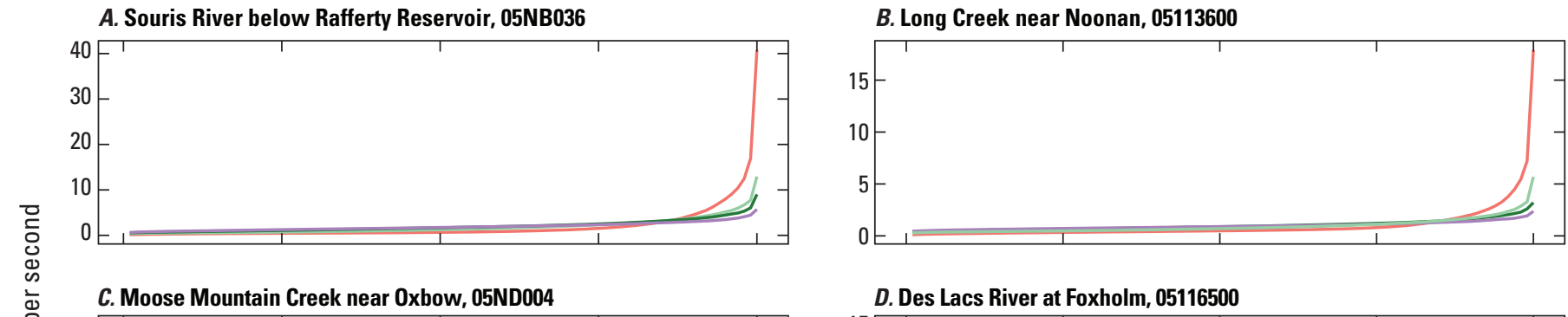

D. Des Lacs River at Foxholm, 05116500

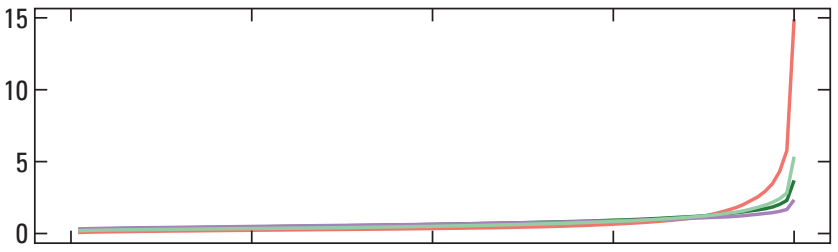

F. Souris River above Minot, 05117500

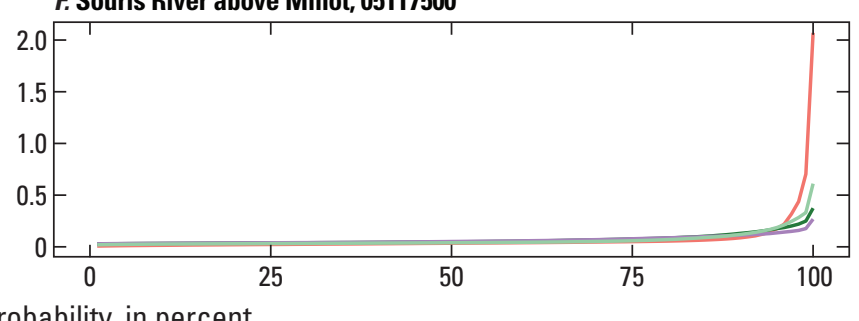

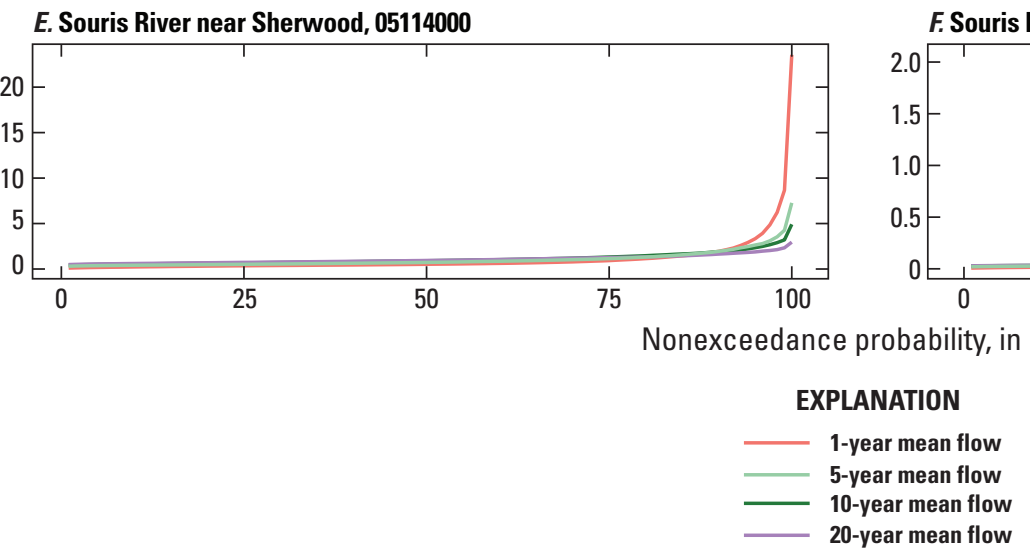

Figure 12. Nonexceedance probability for long-term streamflow means at sites in Saskatchewan and North Dakota. $A$, Souris River below Rafferty Reservoir; $B$, Long Creek near Noonan (above Boundary Reservoir); $C$, Moose Mountain Creek near Oxbow; $D$, Souris River near Sherwood; E, Des Lacs River at Foxholm; F, Souris River above Minot. 
Table 4. Streamflows at the Souris River below Rafferty Reservoir, Long Creek near Noonan (above Boundary Reservoir), Moose Mountain Creek near Oxbow; the Souris River near Sherwood, the Des Lacs River at Foxholm, and the Souris River above Minot for the $1-, 5-, 10-$, and 20 -year averaging periods.

[Annual refers to the Canadian water year, November 1 to October 31; Sask., Saskatchewan; yr, year; ND, North Dakota; USGS, U.S. Geological Survey]

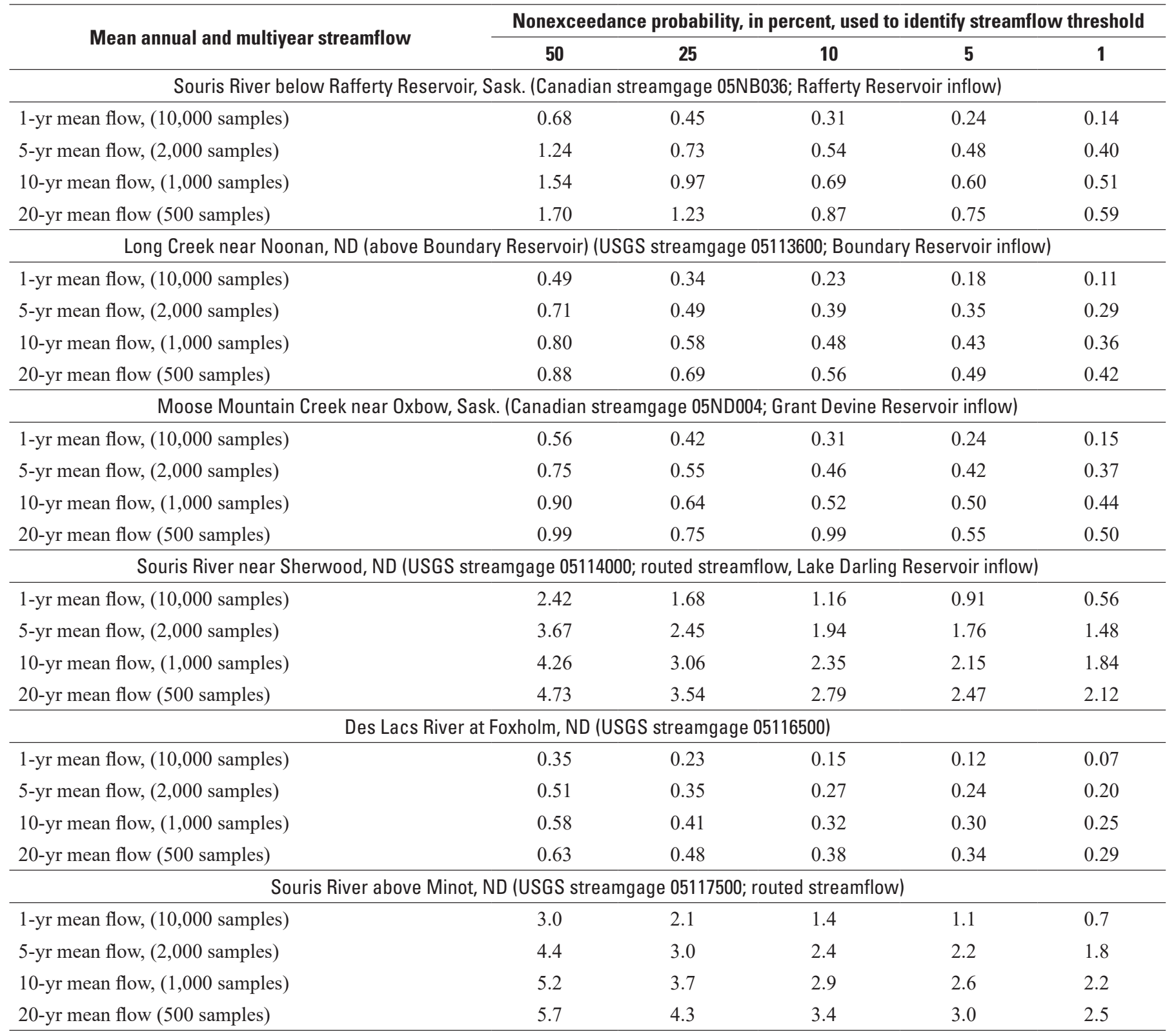

Streamflow quantiles from different averaging periods were compared by taking the ratio of the 5-, 10-, and 20 -year averaging period streamflow and dividing by the 1-year averaging period streamflow (fig. 13). For example, a 5-year averaging period streamflow with a 10-percent nonexceedance probability would be divided by a 1-year averaging period streamflow with a 10-percent nonexceedance probability, resulting in a ratio with a 10-percent nonexceedance probability. Comparing percentiles with a ratio is a way of measuring the variability of streamflow at individual sites and enables comparison of the variability of streamflow quantiles across streams. The purpose of taking the ratio of the differing averaging periods to the 1 -year averaging period was to understand the potential effect of drought on streamflow and the effect of streamflow variability over long periods of time. Two streams with similar mean streamflow volumes can differ in variability with one stream being a less reliable source of water. For example, the 20-year, 50-percent nonexceedance probability of streamflow for all streamflow sites was between 1.5 and 3 times the 1-year, 50-percent nonexceedance probability event, with the minimum value occurring at the Souris River above Minot and the highest values occurring at the Souris 


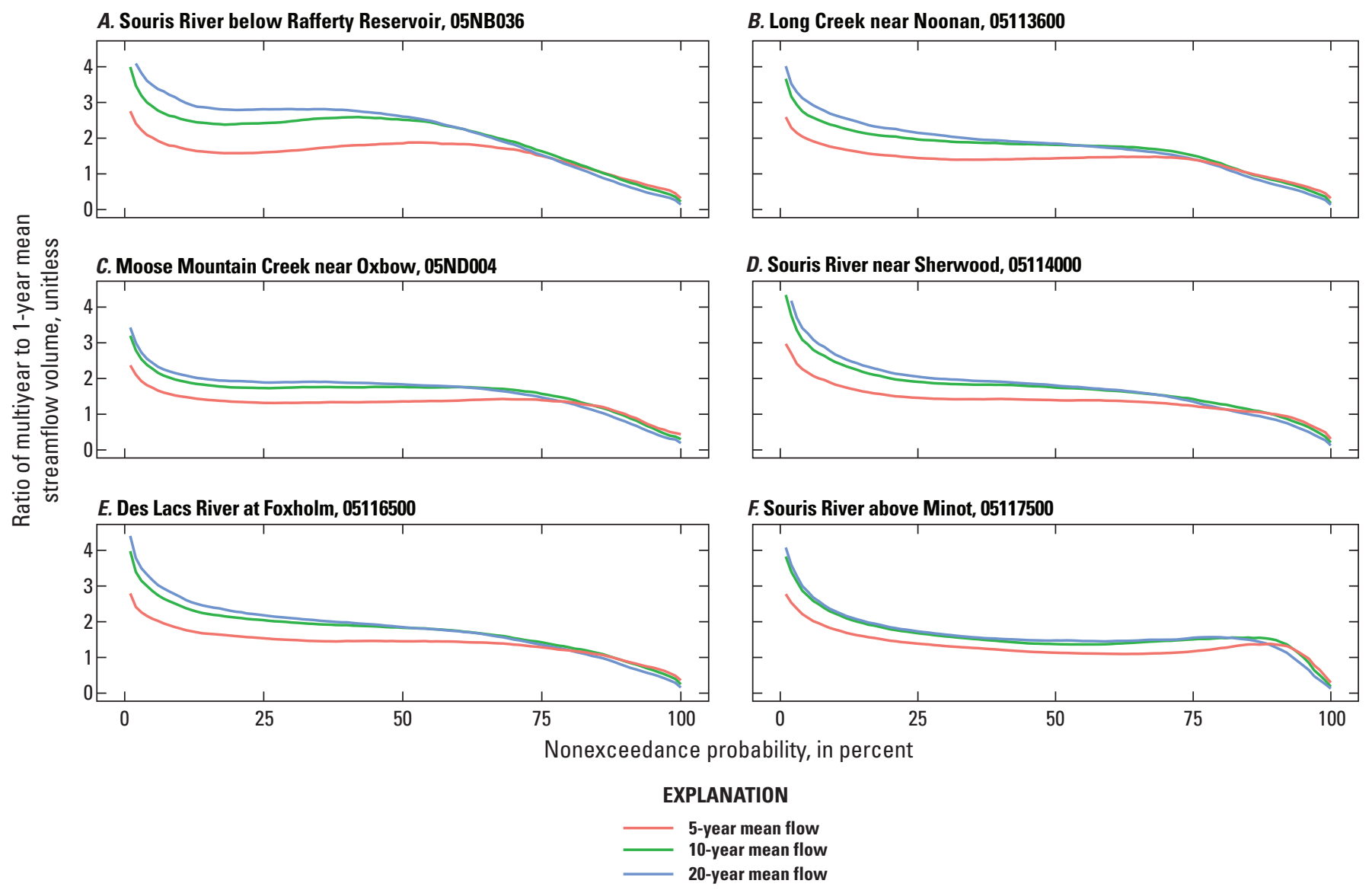

Figure 13. Ratio of 5-, 10-, and 20-year mean streamflow to 1-year mean streamflow by percentile at sites in Saskatchewan and North Dakota. A, Souris River below Rafferty Reservoir; $B$, Long Creek above Boundary Reservoir; $C$, Moose Mountain Creek near 0xbow; $D$, Souris River near Sherwood; $E$, Des Lacs River at Foxholm; $F$, Souris River above Minot.

River below Rafferty Reservoir (table 4). For the driest years, streamflows are low and the ratios are large. As the nonexceedance probability increases, the ratio of multiyear streamflow to 1-year streamflow decreases. Over a multiyear period, low nonexceedance probability is tied to greater mean streamflow than the 1-year mean streamflow. When the nonexceedance probability is high, the 1-year mean streamflow is greater than the multiyear mean streamflow and produces a ratio less than 1 . The spacing between different multiyear ratio curves is valuable because it serves as a way of determining variability over multiyear mean streamflow periods. The Souris River below Rafferty Reservoir is more variable at low nonexceedance probabilities than the other sites presented in fig. 13. In addition, the shape of the nonexceedance probability to ratio curve can be used as a mechanism to understand, on average, how streamflow might begin to recover and how much streamflow could recover relative to an existing condition. For example, the streamflow at the Souris River above Minot is fairly stable compared to the Souris River below Rafferty Reservoir. At higher streamflows, Moose Mountain Creek near
Oxbow has lower mean streamflow relative to the Souris River below Rafferty Reservoir regardless of the averaging period (1-year, 5-year, 10-year, or 20-year); however, when nonexceedance probability decreases, the gap between streamflow ratios at Moose Mountain Creek near Oxbow maintains less variability in its multiyear mean streamflow ratios and could be considered more consistent.

\section{Disaggregated Daily Stochastic Streamflow}

The 10-day stochastic streamflows generated for natural (unregulated) conditions by Kolars and others (2016) were disaggregated to a daily time step for use as input to USACE HEC-ResSim models developed to evaluate operation plans for reservoirs in the Souris River Basin (International Souris River Study Board, 2018). The HEC-ResSim models were 
developed to evaluate alternatives to the current operational plan (United Nations, 1989) using a large range of possible conditions generated by the stochastic modeling and using reconstructed hydrology to simulate historical conditions (U.S. Army Corps of Engineers, 2020) as input. The disaggregation process included the spatial disaggregation of local streamflow from the stochastic WBM to the local streamflow defined in the HEC-ResSim model, the calculation of annual streamflow for the basin in the stochastic and reconstructed hydrology dataset, the identification of the historical year that most closely matches the volume of streamflow in each year of the stochastic streamflow dataset, and the calculation and smoothing of daily streamflow for input to HEC-ResSim model. This section describes the process used to disaggregate the stochastic streamflow data to a daily time step for use in the HEC-ResSim model and the discussion of results including the selection of traces from the 100 100-year stochastic traces (Kolars and others, 2016) for evaluation in an alternative focused HEC-ResSim model.

\section{Methods and Data for Generation of Disaggregated Daily Streamflow}

Two datasets were used to develop the daily stochastic streamflow. The first was stochastically generated local streamflow data produced by each of the 15 subbasins for the Souris River Basin (Kolars and others, 2016). The stochastically generated streamflow data for each subbasin have a time step of 10 days, and each year contains 36 time steps. Each trace is 100 years long, and 100 spatially and temporally correlated stochastic traces were generated for each of the $15 \mathrm{sub}$ basins using the methods detailed in Kolars and others (2016).

The second dataset is the local streamflows from the reconstructed hydrology of the Souris River Basin for the period of 1930-2018 (U.S. Army Corps of Engineers, 2020). The reconstructed hydrology used in the disaggregation process was distinct from the reconstructed hydrology model used in Kolars and others $(2016,2019)$ because it was extended from the period of 1946-2013 to 1930-2018. This dataset was used because the 1930s are the longest period of severe drought in the historical record. The reconstructed hydrology dataset was used to define required inputs to the Souris River HEC-ResSim model and to develop daily stochastic streamflow time series for input to the HEC-ResSim model in the evaluation of alternatives.

In the Souris River Basin reconstructed hydrology model, 26 stream sites along the Souris River require daily time series of streamflow that are either defined as inflow or local streamflow (table 5 and fig. 2). The input of the 26 daily time series into the Souris River Basin HEC-ResSim model was used in combination with a calibrated streamflow model to calculate streamflow at points in which input data are not required. Local streamflow can be defined as the streamflow resulting from runoff from one subbasin without the addition of water from upstream subbasin runoff or base flow contributing to streamflow. Because of the difference in streamflow sites in the stochastic WBM model and the needed inputs to the Souris River HEC-ResSim model, a method needed to be adapted to spatially disaggregate stochastic streamflow time series. The streamflow and local streamflow inputs for the reconstructed hydrology HEC-ResSim model (U.S. Army Corps of Engineers, 2013a) are the same as those for input to a HECResSim model for assessment of alternatives and existing operations for the Souris River Basin. In addition, the 10-day time series of the stochastic streamflow dataset required temporal disaggregation to a daily time step.

\section{Spatial Disaggregation}

The boundary of the Souris River Basin was delineated to determine contributing areas for selected streamgages as outlet points in Canada and the United States for the stochastic WBM described in Kolars and others (2016) (fig. 2). The HEC-ResSim model for the Souris River Basin requires streamflow input at a more refined spatial scale than was available from the stochastic streamflow WBM. In addition, the HEC-ResSim model does not require any information about the basin's boundaries, physical characteristics, or meteorological time series to simulate streamflow; instead, it relies solely on time series at streamgages and estimated local streamflow points to calculate streamflow at other points along a river.

To address the issue of misalignment between the stochastic streamflow sites and the HEC-ResSim model input sites, subbasins were defined for each streamflow point in the HEC-ResSim reconstructed hydrology model for the Souris River Basin. The stochastic streamflow from each of the 15 subbasins was broken up according to the percentage of area within the subbasins identified for the streamflow points in the HEC-ResSim model. The HEC-ResSim model requires input at 26 stream sites whereas the WBM requires input at 15 sites. Local stochastic streamflow time series were redistributed for use in HEC-ResSim model. The redistribution of the local stochastic streamflow was completed by estimating the percentage of the stochastic WBM basin boundaries that overlapped the harmonized USGS hydrologic unit code 12 and hydrologic unit code 10 maps (U.S. Geological Survey, 2017) for each of the USACE HEC-ResSim models (U.S. Army Corps of Engineers, 2020) local streamflow input locations.

Each subbasin stochastic streamflow trace was multiplied by the percentage of area associated with an overlapping subbasin for the HEC-ResSim model (table 5). When a subbasin from the HEC-ResSim model was composed of more than one of the stochastic WBM model subbasins, the total of the monthly percentage of local streamflow from each trace was summed to create a new time series to represent monthly stochastic streamflow for the HEC-ResSim model subbasin. 
Table 5. Multiplication factors for distribution of stochastic streamflow by basin to local streamflow locations.

[Sask., Saskatchewan; ND, North Dakota; NWR, National Wildlife Refuge]

\begin{tabular}{|c|c|c|c|c|}
\hline $\begin{array}{l}\text { Map identification } \\
\text { number (fig. 2) }\end{array}$ & Local flow point description & $\begin{array}{l}\text { Stochastic watershed } \\
\text { (fig. 2) }\end{array}$ & $\begin{array}{l}\text { Area, in square } \\
\text { kilometers }\end{array}$ & $\begin{array}{c}\text { Multiplication } \\
\text { factor }\end{array}$ \\
\hline 1 & Inflow to Rafferty Reservoir, Sask. & Rafferty & 6,267 & 1.00 \\
\hline 2 & Inflow to Boundary Reservoir, Sask. & Noonan & 4,374 & 1.00 \\
\hline 3 & Inflow to Grant Devine Reservoir, Sask. & Grant Devine & 6,094 & 1.00 \\
\hline 4 & Short Creek at Roche Percee, Sask. & Sherwood & 836 & 0.15 \\
\hline 5 & Local flow at Roche Percee, Sask. & Sherwood & 1,171 & 0.21 \\
\hline 6 & $\begin{array}{l}\text { Local flow at Glen Ewen, Sask. (Oxbow to Glen } \\
\text { Ewen) }\end{array}$ & Sherwood & 112 & 0.02 \\
\hline 7 & $\begin{array}{l}\text { Local flow at Oxbow, Sask. (Roche Percee to } \\
\text { Oxbow) }\end{array}$ & Sherwood & 3,067 & 0.55 \\
\hline 8 & $\begin{array}{l}\text { Local flow to Souris River near Sherwood, ND (Glen } \\
\text { Ewen to Sherwood) }\end{array}$ & Sherwood & 390 & 0.07 \\
\hline 9 & Local flow at Des Lacs River Confluence, ND & Minot & 283 & 0.73 \\
\hline 10 & Des Lacs River at Foxholm, ND & Foxholm, Minot & 64 & 0.05 \\
\hline 11 & Des Lacs River at Baden, ND & Des Lacs & 2,456 & 1.00 \\
\hline 12 & Local flow to Souris River above Minot, ND & Minot & 37 & 0.03 \\
\hline 13 & Local flow to Souris River above Lake Darling, ND & Foxholm & 1,282 & 0.95 \\
\hline 14 & Boundary Creek near Landa, ND & Westhope & 771 & 0.11 \\
\hline 15 & Cut Bank Creek at Upham, ND & Westhope & 1,797 & 0.25 \\
\hline 16 & Stone Creek near Kramer, ND & Westhope & 408 & 0.06 \\
\hline 17 & $\begin{array}{l}\text { Local flow to Souris River upstream from pool } 357 \\
\text { near Westhope (J. Clark Salyer NWR), ND }\end{array}$ & Westhope & 1,760 & 0.25 \\
\hline 18 & $\begin{array}{l}\text { Local flow to Souris River upstream from dam } 341 \\
\text { (J. Clark Salyer NWR), ND }\end{array}$ & Westhope & 94 & 0.01 \\
\hline 19 & $\begin{array}{l}\text { Local flow to Souris River upstream from dam } 320 \\
\text { (J. Clark Salyer NWR), ND }\end{array}$ & Westhope & 2,101 & 0.30 \\
\hline 20 & Local flow to Souris River at Velva, ND & Verendrye & 1,364 & 0.71 \\
\hline 21 & Deep River near Upham, ND & Deep River & 2,491 & 1.00 \\
\hline 22 & Willow Creek near Willow City, ND & Willow & 2,934 & 1.00 \\
\hline 23 & Wintering River at Karlsruhe, ND & Wintering Creek & 1,402 & 1.00 \\
\hline 24 & Local flow to Souris River at Bantry, ND & Bantry & 1,091 & 1.00 \\
\hline 25 & Local flow to Souris River at Verendrye, ND & Verendrye & 557 & 0.29 \\
\hline 26 & $\begin{array}{l}\text { Local flow to Souris River upstream from dam } 332 \\
\text { (J. Clark Salyer NWR), ND }\end{array}$ & Westhope & 129 & 0.02 \\
\hline
\end{tabular}

\section{Time-Series Disaggregation of Monthly Streamflow to Daily Streamflow}

The temporal disaggregation of the spatially disaggregated stochastic streamflow traces was a process that involved (1) assignment of a daily time series to all traces, (2) determination of the historical calendar year with the closest volume of streamflow basinwide to each of the 10,000 trace years of stochastic hydrology and assignment of the historical year to the stochastic trace year, (3) bias correction for historical years that were favored in step 2, (4) calculation of daily to monthly ratios of streamflow volume in the historical record, (5) alignment of daily time series to stochastic time series, (6) calculation of streamflow volume for each month of the stochastic streamflow traces, (7) alignment of the assigned daily time series from historical years matched by volume to year of stochastic streamflow in trace after bias correction, (8) generation of daily time series for monthly stochastic streamflow volumes, and (9) application of decision rules and smoothing to address method limitations. 
The HEC-ResSim model requires that local streamflow inputs are a time series with an assigned date. The stochastic streamflow time series were reassigned to dates between January 1, 3000, and December 31, 3099. The range of dates does not have any implied meaning for climate or hydrology in the Souris River Basin and was used solely to distinguish the traces from historical predicted daily streamflow under different alternative scenarios. Because each year in the stochastic streamflow maintains temporal correlation, the years are numbered 1 through 100.

The streamflow traces were aggregated from 10-day stochastic streamflow time series to a monthly and annual time series of streamflow volume. The daily historical reconstructed hydrology dataset was also aggregated to monthly and annual time series. The purpose of the aggregation was to prepare the stochastic streamflow time series for conversion to daily time series. Each annually aggregated stochastic streamflow time series was matched with the year from the historical reconstructed hydrology annual time series that had the closest annual streamflow volume using the root mean squared difference equation in equations $1-2$. For each trace, the list of historical years that most closely matched was ordered by year relevant to the stochastic streamflow annual time series (eq. 3).

$$
\begin{gathered}
V_{t, i}, \quad V_{R H, i}=\sum_{j=1}^{n=26} V_{s, j}, \\
S_{i}=\sqrt{V_{t, i}^{2}-V_{R H, j}^{2}}, \\
Y_{j} \in \min \left(S_{i}\right),
\end{gathered}
$$

\begin{tabular}{|c|c|}
\hline$n$ & $\begin{array}{l}\text { refers to the number of samples to } \\
\text { be summed; }\end{array}$ \\
\hline$V_{t, i}$ & $\begin{array}{l}\text { is the annual volume of streamflow basinwide, } \\
t \text {, for a given year, } i \text {, in a stochastic } \\
\text { streamflow trace; }\end{array}$ \\
\hline$V_{R H, i}$ & $\begin{array}{l}\text { is the annual volume of streamflow basinwide } \\
\text { for a given year in the reconstructed } \\
\text { hydrology dataset, where RH refers to } \\
\text { "reconstructed hydrology"; }\end{array}$ \\
\hline$V_{s, j}$ & $\begin{array}{l}\text { is the annual volume of streamflow at a given } \\
\text { site for a given year, where } s \text { references an } \\
\text { individual site's annual streamflow volume } \\
\text { and } j \text { is a specific year; }\end{array}$ \\
\hline$S_{i}$ & $\begin{array}{l}\text { is the root mean squared difference between } \\
\qquad V_{t, i} \text { and } V_{R H, j} ;\end{array}$ \\
\hline$Y_{j}$ & $\begin{array}{l}\text { is the historical year associated with the } \\
\text { minimum } S_{i} \text { for a given trace year; and }\end{array}$ \\
\hline$i, j$ & refer to a time step. \\
\hline
\end{tabular}

where

The purpose of the historical years list was to take the shape of the daily time series of streamflow for each site and apply the shape to the stochastic monthly streamflow to create a stochastic daily streamflow time series for each site. The frequency of historical years in the historical years list was evaluated (fig. 14A). The annual historical streamflow volumes are skewed towards lower streamflow volumes that are less than 1,000 cubic decameters (fig. 15). Many of the 10,000 trace years in the stochastic streamflow volume dataset also have annual streamflow volumes that are less than 1,000 cubic decameters (fig. 16). The calculations for closest historical year streamflows were repeated, and the historical years of 1930, 1934, and 1936 accounted for more than 50 percent of the years with the closest volume to stochastic streamflow trace years in the 10,000 trace years of stochastic streamflow. Any of the years in the period of 1930-40 and 1988-94 are likely to have some of the lowest streamflow volumes (fig. 15) and lack streamflow variability of more moderate streamflow years. Although the streamflow volumes of the dry historical annual years are the most similar to the stochastic streamflow years (figs. 14 and 16), variability in streamflow patterns is desirable and the driest of historical years tend to lack variability. Because of the bias towards matching stochastic streamflow volume to a few dry historical years, greater variability of the streamflow time-series shape was introduced (fig. 14B). For the historical years that most closely matched more than 400 of the 10,000 trace years of streamflow, the stochastic traces were replaced with 1 of the 20 closest years (fig. 14B). Selection from 1 of the 20 years was done randomly and used in place of the original historical year.

Each day in the stochastic streamflow time series must be assigned a date between January 1, 3000, and December 31, 3099 , and a daily to monthly streamflow ratio. For each year in the time series of the stochastic streamflow traces, the chosen historical year daily to monthly streamflow ratios were assumed to characterize the stochastic streamflow year daily to monthly streamflow ratios. For example, if year 1 in trace 1 was matched with 1945 , then the daily to monthly streamflow ratio from January 1, 1945, would be the same but for January 1, 3000. If 1945 was selected for a second year, then 3001 would also take on the daily to monthly streamflow ratios from 1945. Historical years and each hypothetical year from 3000 through 3099 contain 365 or 366 days, depending on the occurrence of leap year, making it possible for there to be either one too many or one missing daily to monthly streamflow ratio in the month of February. When a historical year had more days in February than the hypothetical year, the decision was made to remove February 29 and the associated daily to monthly streamflow ratio. If, however, the hypothetical year contained a leap year day, the daily to monthly streamflow ratio from February 28 of the historical year was also applied to the hypothetical leap year day. To shape the stochastic streamflow with the historical ratio of daily to monthly streamflow, the daily to monthly ratio of streamflow volume from the reconstructed hydrology was placed in a vector by the order or the stochastic year for each trace. The daily to monthly ratios of streamflow were assigned a date from January 1, 3000, to December 31, 3099, based on their location associated with the stochastic time series. 

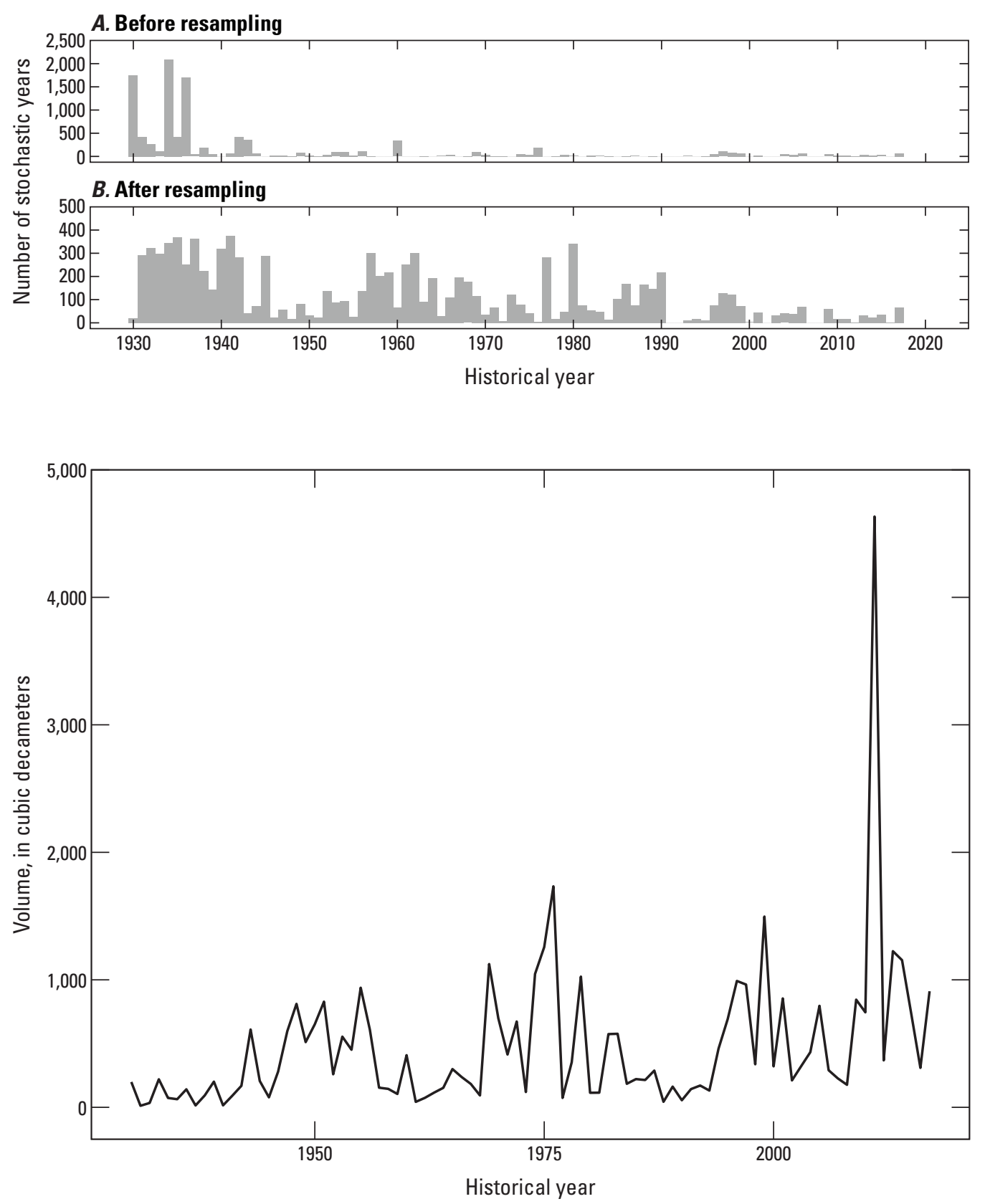

Figure 14. Prevalence of historical years with streamflow volume closest to stochastic streamflow. $A$, before resampling; $B$, after resampling for the Souris River Basin.
Figure 15. Annual historical streamflow volume for the Souris River Basin, 1930-2018.
Decision rules were developed to correct several issues that arose during the disaggregation process. Issues include misalignment in days of year from historical to future, maintenance of streamflow volume from stochastic time series, and the presence of negative daily ratios in the reconstructed hydrology. If a year from the reconstructed hydrology had 366 days and the new time sequence did not, the leap year day ratio would be removed. If there were only 365 days in the daily ratios of streamflow but there needed to be 366 days, the ratio of streamflow on February 28 would also be applied to February 29. In some cases, streamflows in the reconstructed hydrology were negative (U.S. Army Corps of Engineers,
2020), and they were changed to zero. In some cases, the monthly total volume of streamflow from the reconstructed hydrology was $0 \mathrm{~m}^{3}$, and this could result in loss of daily streamflow volume in the stochastic dataset. In months where streamflow volume was greater than $0 \mathrm{~m}^{3}$ in the stochastic hydrology but the multiplier from the reconstructed hydrology was 0 , resulting in a continuous month of $0 \mathrm{~m}^{3}$ daily streamflow volume, the $0 \mathrm{~m}^{3}$ daily streamflow volume for that month would be replaced with the monthly streamflow volume from the stochastic hydrology divided evenly by the number of days in the month. These modified periods in the stochastic daily streamflow traces with constant streamflow volume do not 


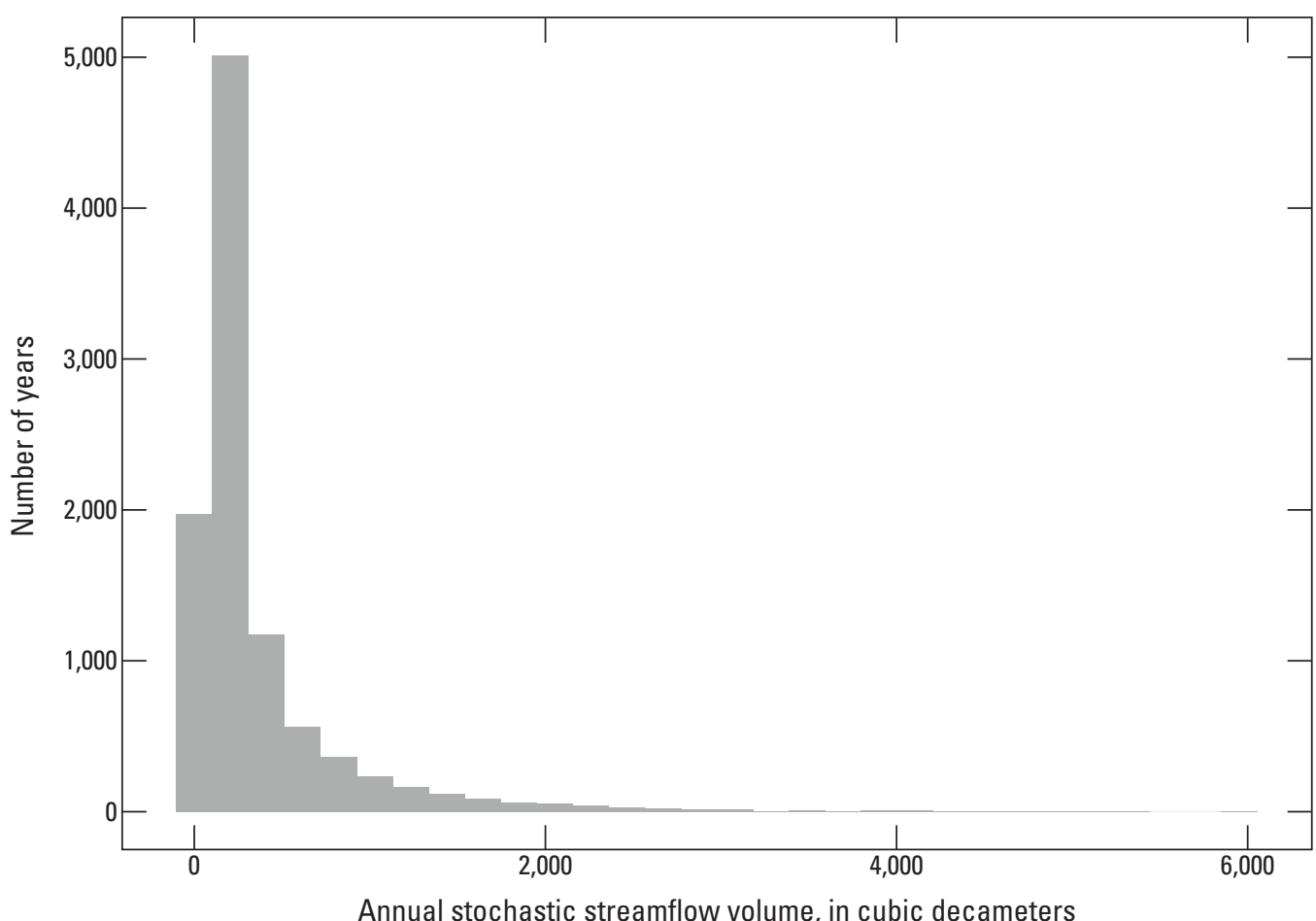

Figure 16. Distribution of annual stochastic streamflow volume for the Souris River Basin. accurately reflect the variability of low streamflow periods but were intended to maintain the full volume of streamflow in the original stochastic streamflow traces.

Daily stochastic streamflows for the Souris River Basin were calculated by multiplying the daily to monthly historical streamflow volume ratio by the monthly volume of stochastic streamflow at each of the 26 stream sites. The daily stochastic streamflow volume was then converted to streamflow by dividing by 86,400 seconds per day. Although annual stochastic streamflow for the basin was intentionally matched to similar historical years for disaggregation, some stochastic traces included streamflow events that are not physically reasonable; for example, some floods were large in magnitude but only spanned 1 day and lacked a rising and receding limb. To disperse stochastic streamflow traces in a more reasonable manner, a Gaussian kernel smoothing function (Rosenblatt, 1956; Parzen, 1962) was applied to all traces. The kernel smoothing function is expressed in equations 4 through 6 . A bandwidth of $b=2$ was used in the kernel smoothing function.

$$
\begin{gathered}
\hat{f}_{t}=\sum_{i=1}^{n} x_{i} w_{i}(t), \\
w_{i}(t)=K\left(\frac{t-i}{b}\right) / \sum_{j=1}^{n} K\left(\frac{t-j}{b}\right), \\
K(z)=\frac{1}{\sqrt{2 \pi}} \exp \left(\frac{-z^{2}}{2}\right),
\end{gathered}
$$

where

$$
\begin{aligned}
\hat{f}_{t} & \text { is the resulting smoothed value; } \\
i, j & \text { refer to a time step; } \\
n & \text { refers to the number of samples to } \\
& \text { be summed; } \\
w_{i}(t) & \text { is the weighting parameter at time, } t ; \\
x_{i} & \text { is the unsmoothed streamflow at point, } i ; \\
t & \text { is the time step at which the calculation is } \\
& \text { taking place; } \\
b & \text { is the bandwidth or degree of weighting; } \\
K(z) & \text { is the selected distribution model (for } \\
z & \text { is the bandwidth of values to be smoothed. }
\end{aligned}
$$

\section{Localized Daily Streamflow and Stochastic Trace Selection}

As discussed, the ISRSB focused on (1) summer streamflow, (2) water supply, and (3) apportionment. Many of the trace selections were made using the monthly unregulated streamflow data because mean monthly streamflow is closely related to daily streamflow. The exception to this was the use of daily streamflow in the selection of traces for apportionment. Traces of stochastic streamflow may be characterized for use in evaluating alternatives in the HEC-ResSim model by focusing on percentiles of streamflow that are representative of the driest and wettest conditions, or a combination of the two. Traces holding the closest seasonal or annual values to specific thresholds were selected; that is, a trace could be 
selected because of a trait in one Canadian water year at one or more sites. Although the full length of a trace will have the statistical characteristics inherent to the Souris River Basin, some periods may have events that are outside the realm of possibility under natural conditions; for example, periods where streamflow is constant over a month or several months exist, and such periods would not happen under unregulated conditions.

In general, traces were selected using a percentile of streamflow as a threshold; for example, traces with summer floods were selected if Grant Devine and Rafferty Reservoirs experienced inflows that exceeded the 10-percent exceedance probability of streamflow in the same month of summer. Because this method produces all events that measure greater than the threshold, the difference between the streamflow event and threshold is also calculated. The year with the smallest difference in streamflow, from an individual trace, was then chosen to represent a summer flood. This process could be repeated to find a trace that most closely matches another percentile or to determine the next closest trace(s). The details of the trace selection for (1) summer streamflow, (2) water supply, and (3) apportionment are provided in this section.

Summer streamflow traces were selected by the occurrence of flood events on Moose Mountain Creek near Oxbow and the Souris River below Rafferty Reservoir. All 10,000 trace years of streamflow were evaluated. For each summer, the month with the largest inflow to Grant Devine and Rafferty Reservoirs was identified independently. Traces in which the 10-percent exceedance probability of annual maximum monthly mean streamflow event co-occurred at both sites were selected for testing alternatives in the HEC-ResSim model. The 10-percent exceedance probability of annual maximum monthly mean streamflow at the Souris River below Rafferty Reservoir and Moose Mountain Creek near Oxbow is 31.5 and $14.3 \mathrm{~m}^{3} / \mathrm{s}$ (table 1), respectively. These criteria resulted in 758 co-occurring 10-percent (or greater) exceedance probability of flood events at both reservoirs during the same month (table 3). After the identification of the co-occurring flood events, the difference between the threshold and flood event at each reservoir was taken and squared. The sums of the squares were then added together and finally the square root was taken. The smallest root mean squared difference was indicative of the year in the traces with the closest result to the thresholds. Traces were selected if they had not been selected for another purpose and they contained an event with one of the five smallest root mean squared differences.

Trace selection for water supply was investigated from the perspective of extended periods of hydrologic drought reflected in annual and multiannual year mean streamflow. Traces were selected when mean 5-year streamflow was less than the 10-percent nonexceedance probability for inflows to Rafferty and Grant Devine Reservoir (table 4). The root mean squared difference was used to identify traces closest to the thresholds at both reservoirs. Selection of traces with extended periods of drought allow modelers to determine when water supply becomes challenged by a lack of water. In terms of drought, modelers can explore what conditions might pose risk to the communities in Saskatchewan. Use of multiple scenarios also could serve as a sensitivity analysis to see if shorter events differ in terms of water supply compared to longer events with similar streamflows.

The apportionment of streamflow to the United States is determined at the beginning of each calendar year, but fall apportionment is being evaluated, given the concern regarding flooding in spring and summer after a wet fall with saturated ground. However, it might be helpful to know the potential for having a dry spring and a wet fall and the general characteristics of these events. This is particularly relevant to moving the date in which apportionment is calculated because lowering water levels in the Canadian reservoirs to mitigate potential flooding may increase risk to water supply. Characterization of streamflow associated with a dry or wet condition was evaluated at Rafferty, Boundary, Grant Devine, and Lake Darling Reservoirs using historical (table 6) and stochastic (table 7) datasets. The relation between streamflow volume in spring and fall meteorological conditions was evaluated using streamflow and the SPEI (Vicente-Serrano and others, 2010). Daily stochastic streamflow for all streamflow sites was characterized by ranking daily spring streamflow from highest to lowest for each year and then selecting the top 30 days. The mean of the top 30 days of spring streamflow was then calculated. The mean of the 30-day maximum streamflows from spring were evaluated in terms of their quantiles. For traces that were selected, all sites were required to have streamflow with less than a 4-percent nonexceedance probability of spring streamflow (table 6). Specific interest was placed on how the mean of the 3-month lagged SPEI and 12-month lagged SPEI calculated from November 1 to the appropriate lag month relate to the streamflow retrieved from the 4-percent nonexceedance probability of spring streamflow for trace selection. A wet fall is defined using the mean of the 3- and 12-month SPEI values, with "wet" corresponding to an SPEI value greater than 0.5. SPEI is calculated independently at Rafferty, Grant Devine, and Lake Darling (local streamflow only) Reservoirs. A dry spring is defined using the mean streamflow from the highest 30 days of inflow into the reservoir during March through May. This computation was completed independently for each reservoir. A wet fall/dry spring year in the stochastic streamflow dataset is classified as a year in which Rafferty, Grant Devine, and Lake Darling Reservoirs experience a "wet fall" followed by a "dry spring." Of the 10,000 trace years in the stochastic record, 34 years meet this wet fall/dry spring criterion. The characterization of the 30-day maximum spring streamflow at each site against its mean 3-month and 12-month lagged SPEI is presented in table 7.

For the historical period of 1946-2013, the wet fall and dry spring condition was identified at Rafferty (no years), Grant Devine (no years), Boundary $(1959,1991)$, and Lake Darling (1993) Reservoirs (table 6). The drainage basin upstream from Boundary Reservoir experienced a dry spring in 1959 and 1991 that was preceded by a wet fall. The meteorological conditions at Lake Darling Reservoir were 
Table 6. Historical prevalence of wet fall and dry spring on the Souris River below Rafferty Reservoir (natural streamflow), Long Creek near Noonan, Moose Mountain Creek near Oxbow (natural streamflow), and local flow to Souris River above Lake Darling.

[Streamflow was retrieved from the U.S. Army Corps of Engineers reconstructed hydrology model for historical period of 1946 to 2013 (U.S. Army Corps of Engineers, 2013b). 4-percent (\%) nonexceedance probability, when standardized precipitation evapotranspiration index (SPEI) is greater than or equal to ( $\geq$ ) $0.5 ; Q_{s p 30}$, mean streamflow of the 30 highest days of streamflow, in cubic meters per second; wet fall is defined as the mean 3-month and 12-month SPEI with a value of 0.5 or greater associated with estimated meteorological data closest to reservoir (August through October are identified as having a wet condition); dry spring is defined as the mean streamflow of the 30 highest days of streamflow from March through May]

\begin{tabular}{|c|c|c|}
\hline Reservoir inflow used in evaluation & $\begin{array}{l}4 \% \text { annual nonexceedance } \\
\text { probability for } \boldsymbol{Q}_{s p 30}\end{array}$ & $\begin{array}{l}\text { Historical years that meet wet fall (SPEI } \geq 0.5 \text { ) and dry spring } \\
\text { criteria (streamflow is less than the } 4 \% \text { nonexceedance prob- } \\
\text { ability) by site }\end{array}$ \\
\hline $\begin{array}{l}\text { Long Creek near Noonan (Boundary } \\
\text { Reservoir inflow) }\end{array}$ & 0.00 & 1959,1991 \\
\hline $\begin{array}{l}\text { Local flow to Souris River above Lake } \\
\text { Darling }\end{array}$ & 3.51 & 1993 \\
\hline
\end{tabular}

Table 7. Percentile of mean of 30 highest days of spring (March-May) streamflow as a function of previous November 1 mean standardized precipitation evapotranspiration index for a lag of 3 months and 12 months.

[SPEI, standardized precipitation evapotranspiration index; $Q_{s p 30}$, mean streamflow of the 30 highest days of streamflow, in cubic meters per second; $\geq$, greater than or equal to; >, greater than; $<$, less than]

\begin{tabular}{|c|c|c|c|c|c|c|}
\hline \multirow{2}{*}{$\begin{array}{l}\text { Mean of 3-month and 12-month lagged } \\
\text { SPEI on November } 1 \text { at reservoirs }\end{array}$} & \multicolumn{6}{|c|}{ Nonexceedance probability of $\boldsymbol{Q}_{s p 30}$} \\
\hline & 50 & 75 & 90 & 95 & 96 & 99 \\
\hline \multicolumn{7}{|c|}{ Souris River below Rafferty Reservoir (Rafferty Reservoir inflow) } \\
\hline $\mathrm{SPEI} \geq 0.5$ & 8 & 21.1 & 58 & 86.4 & 96 & 158.8 \\
\hline $0.5>\mathrm{SPEI} \geq 0$ & 5.7 & 11.8 & 31.3 & 59.2 & 68.3 & 116.5 \\
\hline $0>\mathrm{SPEI} \geq-0.5$ & 5.3 & 9.7 & 28.3 & 51.5 & 60.6 & 115.9 \\
\hline SPEI $<-0.5$ & 4.7 & 7.3 & 18.9 & 33.3 & 39.5 & 89.1 \\
\hline \multicolumn{7}{|c|}{ Long Creek near Noonan (Boundary Reservoir inflow) } \\
\hline $\mathrm{SPEI} \geq 0.5$ & 2.7 & 4.9 & 11.3 & 19 & 22.3 & 37 \\
\hline $0.5>\mathrm{SPEI} \geq 0$ & 2.6 & 4.7 & 11.1 & 19.2 & 21 & 37.6 \\
\hline $0>\mathrm{SPEI} \geq-0.5$ & 2.6 & 4.5 & 10.3 & 17.6 & 20.5 & 39.3 \\
\hline SPEI $<-0.5$ & 2.6 & 4.6 & 10.3 & 18 & 20.1 & 36.8 \\
\hline \multicolumn{7}{|c|}{ Moose Mountain Creek near Oxbow (Grant Devine Reservoir inflow) } \\
\hline $\mathrm{SPEI} \geq 0.5$ & 5.7 & 10.6 & 26.2 & 46.5 & 54.4 & 85 \\
\hline $0.5>\mathrm{SPEI} \geq 0$ & 5 & 7.6 & 16.5 & 30.9 & 37.3 & 74.6 \\
\hline $0>\mathrm{SPEI} \geq-0.5$ & 4.7 & 6.8 & 13.8 & 24.8 & 28.7 & 63.5 \\
\hline SPEI $<-0.5$ & 4.3 & 5.9 & 10.9 & 19 & 24.4 & 60.9 \\
\hline \multicolumn{7}{|c|}{ Local flow to Souris River above Lake Darling } \\
\hline $\mathrm{SPEI} \geq 0.5$ & 0.1 & 0.2 & 0.5 & 1 & 1.2 & 2.4 \\
\hline $0.5>\mathrm{SPEI} \geq 0$ & 0.1 & 0.2 & 0.3 & 0.5 & 0.6 & 1.3 \\
\hline $0>\mathrm{SPEI} \geq-0.5$ & 0.1 & 0.2 & 0.3 & 0.4 & 0.5 & 1.2 \\
\hline $\mathrm{SPEI}<-0.5$ & 0.1 & 0.1 & 0.2 & 0.3 & 0.3 & 0.8 \\
\hline
\end{tabular}


also indicative of a wet fall in calendar year 1992 with a wet spring defined as the accumulation of streamflow from all upstream watersheds in 1993. The headwaters of the Souris River below Rafferty Reservoir and Moose Mountain Creek near Oxbow did not contain any years in the historical period that met the criteria. No instances were in the historical record in which the spatial extent of the wet fall and dry spring at multiple sites coincided with each other. Despite the lack of spatial consistency in what is considered a wet fall and dry spring, it is informative to investigate years in the historical and stochastic dataset to illustrate the effect of shifting the apportionment year because, as a result of a wet fall, the reservoirs will be drawn down. Shifting the apportionment year enables Saskatchewan to count drawdown releases made in November and December towards its water supply obligation to North Dakota the following spring/summer. Thus, if the basin experiences dry conditions after a wet fall, the amount of water Saskatchewan would be required to provide to North Dakota based on apportionment in the spring/summer, when water supply is more critical, would be less.

Because the wet fall/dry spring scenario needed to evaluate the effectiveness of the apportionment shift is rare in the historical period of record, trace/year combinations within the stochastically produced dataset where a wet fall precedes a dry spring were identified. In table 7, greater detail is provided on the distribution of streamflow as a function of SPEI, with categories of SPEI $<-0.5$ (meteorological drought), $0>\mathrm{SPEI} \geq-0.5,0.5>\mathrm{SPEI} \geq 0$, and $\mathrm{SPEI} \geq 0.5$ (meteorologically greater than normal wet condition). No statistical testing was done to find statistically significant differences among the four sample populations because such testing was beyond the scope of this study.

\section{Stochastically Generated Regulated Streamflow and Reservoir Volume Characteristics}

Characteristics of streamflow and reservoir volume relevant to reservoir operations for four reservoirs in the Souris River Basin were estimated from stochastic modeling output from Kolars and others (2019) from all 100 traces. At each of the four reservoirs, results were provided for monthly inflow volumes, monthly reservoir volumes, the frequency of operational reservoir pool level exceedance, and the occurrence of simultaneous annual maximum monthly mean streamflow events from inflow volume at Rafferty Reservoir and Grant Devine Reservoir.

The first step of evaluating regulated streamflows was to calculate quantiles of monthly inflow to Lake Darling Reservoir and reservoir volume for each of the reservoirs without consideration of any threshold. The quantiles of monthly inflow volume to Lake Darling Reservoir (table 8) and monthly reservoir storage volume for all reservoirs are presented for the 1-, 5-, 10-, 25-, 50-, 75-, 90-, 95-, and 99-percent exceedance probability (table 9). Of the four reservoirs that control streamflow along or to the Souris River, Lake Darling Reservoir is the only reservoir that takes in water that has already been passed through a control structure. Boundary Reservoir, Rafferty Reservoir, and Grant Devine Reservoir receive their inflows through natural processes, and monthly inflows to these locations were previously discussed in the section "Stochastically Generated Natural (Unregulated) Streamflow Characteristics" for annual maximum monthly mean streamflows, seasonal maximum monthly mean

Table 8. Monthly reservoir inflow volume by exceedance probability to Lake Darling Reservoir.

[Values are in cubic decameters; ND, North Dakota; \%, percent]

\begin{tabular}{lrrrrrrrrr}
\hline \multirow{2}{*}{ Month } & \multicolumn{7}{c}{ Exceedance probability of inflow to Lake Darling Reservoir, ND } \\
\cline { 2 - 10 } & $\mathbf{9 9 \%}$ & $\mathbf{9 5 \%}$ & $\mathbf{9 0} \%$ & $\mathbf{7 5 \%}$ & $\mathbf{5 0 \%}$ & $\mathbf{2 5 \%}$ & $\mathbf{1 0 \%}$ & $\mathbf{5 \%}$ & $\mathbf{1 \%}$ \\
\hline January & 0 & 0 & 0 & 0 & 0 & 0 & 50 & 230 & 530 \\
February & 0 & 0 & 0 & 0 & 0 & 20 & 340 & 540 & 880 \\
March & 0 & 0 & 180 & 720 & 1,350 & 2,030 & 2,930 & 4,180 & 14,680 \\
April & 100 & 250 & 400 & 1,180 & 2,880 & 4,670 & 10,260 & 20,040 & 135,240 \\
May & 70 & 130 & 190 & 360 & 770 & 2,030 & 6,110 & 12,130 & 62,810 \\
June & 20 & 40 & 60 & 110 & 230 & 490 & 1,040 & 1,940 & 21,460 \\
July & 0 & 0 & 10 & 20 & 60 & 180 & 510 & 880 & 5,130 \\
August & 0 & 0 & 0 & 0 & 0 & 20 & 120 & 270 & 890 \\
September & 0 & 0 & 0 & 0 & 0 & 0 & 20 & 60 & 350 \\
October & 0 & 0 & 0 & 0 & 0 & 20 & 50 & 100 & 350 \\
November & 0 & 0 & 0 & 0 & 10 & 20 & 50 & 90 & 330 \\
December & 0 & 0 & 0 & 0 & 0 & 0 & 10 & 20 & 160 \\
\hline
\end{tabular}


Table 9. Monthly reservoir storage volume by exceedance probability for Boundary Reservoir, Rafferty Reservoir, Grant Devine Reservoir, and Lake Darling Reservoir.

$[\%$, percent $]$

\begin{tabular}{|c|c|c|c|c|c|c|c|c|c|}
\hline \multirow{2}{*}{ Month } & \multicolumn{9}{|c|}{ Exceedance probability for monthly reservoir volume, in cubic decameters } \\
\hline & $99 \%$ & $95 \%$ & $90 \%$ & $75 \%$ & $50 \%$ & $25 \%$ & $10 \%$ & $5 \%$ & $1 \%$ \\
\hline \multicolumn{10}{|c|}{ Boundary Reservoir } \\
\hline February & 4,100 & 9,700 & 13,400 & 20,900 & 30,200 & 40,000 & 48,200 & 52,800 & 60,500 \\
\hline March & 4,700 & 10,400 & 14,000 & 21,500 & 30,800 & 40,600 & 48,900 & 53,200 & 60,300 \\
\hline May & 7,300 & 13,000 & 16,800 & 24,600 & 34,200 & 44,700 & 53,300 & 57,100 & 61,000 \\
\hline June & 6,800 & 12,500 & 16,400 & 24,100 & 33,900 & 44,400 & 53,100 & 57,200 & 60,900 \\
\hline July & 6,200 & 11,800 & 15,700 & 23,500 & 33,200 & 43,500 & 52,200 & 56,600 & 60,100 \\
\hline August & 5,400 & 11,000 & 14,900 & 22,600 & 32,300 & 42,400 & 51,000 & 55,300 & 58,800 \\
\hline September & 4,700 & 10,300 & 14,100 & 21,800 & 31,400 & 41,300 & 49,800 & 54,100 & 57,400 \\
\hline \multicolumn{10}{|c|}{ Rafferty Reservoir } \\
\hline January & 19,900 & 37,600 & 57,800 & 110,900 & 187,400 & 270,800 & 326,800 & 343,900 & 391,700 \\
\hline February & 20,000 & 37,500 & 57,500 & 110,400 & 186,600 & 269,500 & 325,400 & 342,400 & 389,600 \\
\hline March & 21,800 & 39,500 & 59,600 & 112,000 & 188,400 & 270,900 & 326,100 & 343,000 & 382,500 \\
\hline April & 29,800 & 50,400 & 71,900 & 125,400 & 204,800 & 287,100 & 338,400 & 359,700 & 387,300 \\
\hline May & 32,700 & 54,100 & 76,100 & 133,000 & 214,400 & 299,500 & 355,800 & 373,400 & 490,100 \\
\hline June & 31,000 & 52,000 & 74,100 & 130,800 & 212,700 & 298,100 & 356,600 & 372,000 & 486,300 \\
\hline July & 28,400 & 48,600 & 70,700 & 126,500 & 207,500 & 293,500 & 352,900 & 368,000 & 481,800 \\
\hline January & 80,100 & 83,400 & 85,100 & 86,000 & 86,800 & 87,800 & 89,400 & 91,200 & 94,200 \\
\hline February & 80,000 & 83,300 & 84,900 & 85,800 & 86,700 & 87,800 & 89,500 & 91,200 & 93,900 \\
\hline March & 81,700 & 84,900 & 85,800 & 87,100 & 88,700 & 90,300 & 92,100 & 93,400 & 94,200 \\
\hline April & 87,600 & 90,000 & 91,500 & 93,100 & 94,200 & 94,200 & 94,200 & 94,200 & 111,800 \\
\hline May & 87,800 & 91,000 & 92,800 & 93,900 & 94,200 & 94,200 & 94,200 & 94,200 & 121,000 \\
\hline June & 86,600 & 89,900 & 91,800 & 92,800 & 93,500 & 93,900 & 94,200 & 94,200 & 102,200 \\
\hline July & 84,900 & 88,300 & 90,100 & 91,100 & 91,900 & 92,700 & 93,500 & 94,000 & 94,200 \\
\hline August & 83,100 & 86,400 & 88,200 & 89,200 & 90,000 & 90,900 & 92,000 & 93,000 & 94,200 \\
\hline September & 81,600 & 84,900 & 86,700 & 87,700 & 88,400 & 89,400 & 90,700 & 91,800 & 93,900 \\
\hline October & 80,800 & 84,000 & 85,800 & 86,800 & 87,500 & 88,400 & 89,800 & 91,100 & 94,000 \\
\hline November & 80,400 & 83,700 & 85,400 & 86,300 & 87,100 & 88,000 & 89,500 & 90,900 & 94,000 \\
\hline December & 80,200 & 83,500 & 85,200 & 86,100 & 86,900 & 87,800 & 89,300 & 90,800 & 94,000 \\
\hline
\end{tabular}


Table 9. Monthly reservoir storage volume by exceedance probability for Boundary Reservoir, Rafferty Reservoir, Grant Devine Reservoir, and Lake Darling Reservoir.-Continued

$[\%$, percent $]$

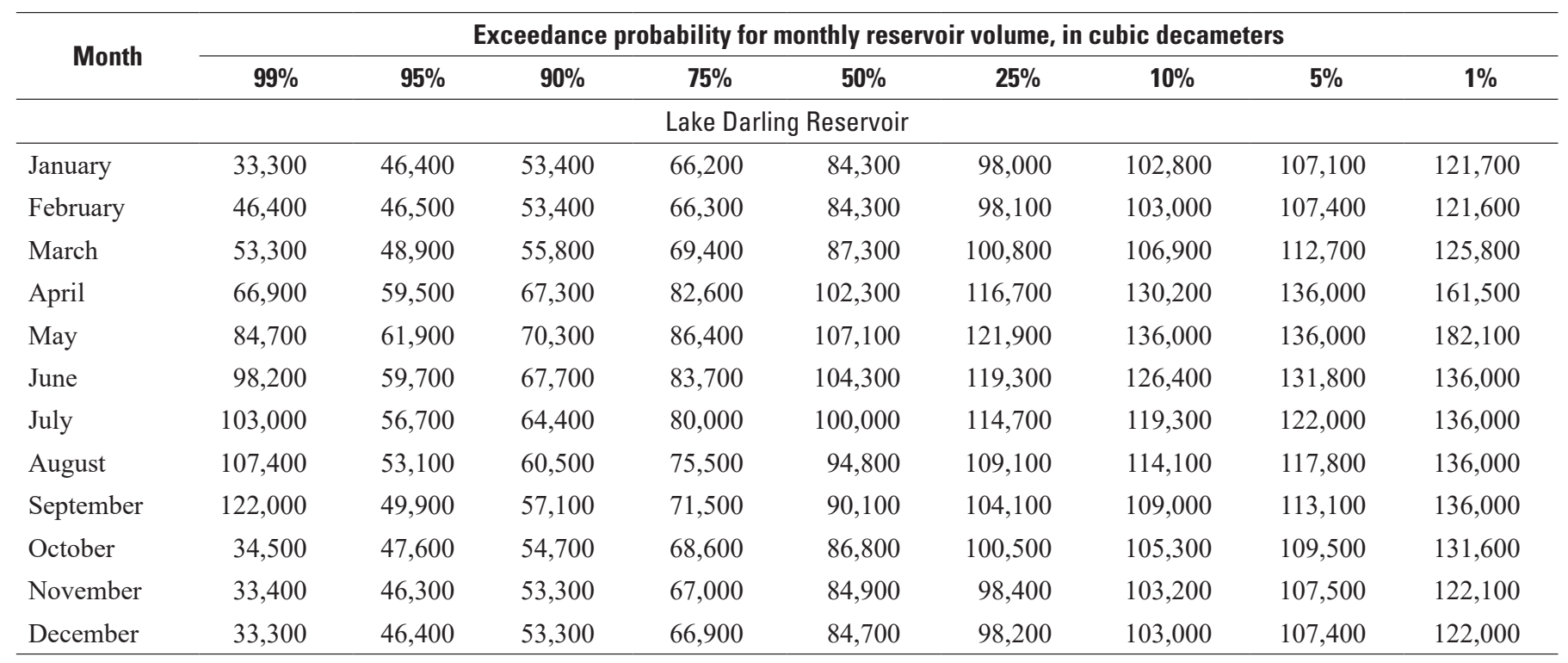

streamflows, and extended periods. Lake Darling Reservoir is upstream from Minot (fig. 1) and provides flood protection to the city of Minot.

The quantile of monthly reservoir volume was estimated for the 1-, 5-, 10-, 25-, 50-, 75-, 90-, 95-, and 99-percent exceedance probability for each month at all four reservoirs (table 9). Monthly reservoir volume was largest during the month of May. The smallest reservoir volumes occurred in December for Grant Devine, Rafferty, and Boundary Reservoirs but occurred in January for Lake Darling Reservoir.
The two main reservoir purposes in the Souris River Basin are for water supply and flood protection. The reservoir pool elevations and the frequency in which the reservoirs are filled to those volumes tell a story about the statistical occurrence of meeting pool levels, which are associated with pool volumes. The number of occurrences in which Boundary, Rafferty, Grant Devine, and Lake Darling Reservoirs meet the MAFL and FSL are presented in table 10.

Table 10. Number of occurrences of maximum allowable flood level and full supply level at Rafferty Reservoir, Boundary Reservoir, Grant Devine Reservoir, and Lake Darling Reservoir.

[MAFL, maximum allowable flood level; FSL, full supply level]

\begin{tabular}{|c|c|c|c|c|}
\hline Condition & Rafferty ${ }^{1}$ & Boundary ${ }^{1}$ & Grant Devine ${ }^{1}$ & Lake Darling $^{2}$ \\
\hline MAFL elevation, in meters & 554 & 560.83 & 567 & 488 \\
\hline Number of occurrences in 10,000 years & 0 & 0 & 26 & 4 \\
\hline Number of occurrences in 10,000 years & 1,142 & 0 & 814 & 641 \\
\hline
\end{tabular}

${ }^{1}$ Elevations are referenced to the Canadian Geodetic Survey of 1928.

${ }^{2}$ Elevations are referenced to the North American Vertical Datum of 1988. 
The water from Boundary Reservoir is used to cool water from the Boundary Power Plant. Boundary Reservoir is not managed to address flooding issues and only has an MAFL to withstand failure. During the 10,000 trace years of simulation, no occurrences of MAFL were met or exceeded in Boundary Reservoir. MAFL was exceeded at Grant Devine Reservoir 26 times and at Lake Darling Reservoir 4 times. Given the few number of times Lake Darling Reservoir experienced this condition, it is possible that the occurrences are outliers. At Grant Devine Reservoir, the estimated risk of the MAFL being exceeded was once every 384 years. Based on the results of the analysis (table 10), it would be expected that the FSL would be surpassed 8 times in a 100-year period at Grant Devine Reservoir and 11 times in a 100-year period at Rafferty Reservoir.

\section{Summary}

The Souris River Basin is a 61,000-square-kilometer basin in the Provinces of Saskatchewan and Manitoba in Canada and the State of North Dakota in the United States. Greater than average snowpack during the winter of 2010-11, preceded by wetter than normal conditions that started in 2008 with an unusually wet fall season in 2010, along with recordsetting rains in May and June 2011, resulted in historically unprecedented flooding in the Souris River Basin. The severity of the 2011 flood led the United States and Canada to request a review of the operating plan described in annex A of the 1989 international agreement for any improvements of reservoir operations and flood control measures in the basin, and the Souris River Basin Task Force was formed. The International Souris River Study Board was then formed in 2017 to carry out the recommendations of the Souris River Basin Task Force laid out in a plan of study. The International Souris River Study Board was tasked with evaluating potential changes to reservoir operations in comparison to existing operations under the 1989 international agreement. To support the International Souris River Study Board, the U.S. Geological Survey (USGS), in cooperation with the North Dakota State Water Commission and the International Joint Commission, used the previously developed unregulated and regulated models and data for stochastic streamflow in the Souris River Basin to characterize climate and streamflow and support selection of streamflow traces based on the characterization. Components of the original stochastic hydrology models and their outputs were used in this phase of the study to (1) characterize historical and stochastic climate and streamflow for the Souris River Basin, (2) disaggregate monthly stochastic streamflow spatially and temporally to meet the needs of the U.S. Army Corps of Engineers, Hydrologic Engineering Center, Reservoir System Simulation model for the Souris River Basin, and (3) discuss selection of disaggregated streamflow traces (simulations) using the characteristics of climate and streamflow.
To characterize climate conditions, precipitation, potential evapotranspiration (PET), and moisture deficit for the Souris River Basin and individual points at Rafferty, Grant Devine, and Lake Darling Reservoirs were determined annually and seasonally. Boundary Reservoir was assumed to have the same climate characteristics of Rafferty Reservoir because of its proximity. The annual basin (November 1-October 31) precipitation for the 50-percent nonexceedance probability is 452 millimeters (mm). Spring (March-May) is the wettest season, followed by summer (June-August), fall (SeptemberNovember), and winter (December-February). The 50-percent nonexceedance probability of the stochastic precipitation was greatest in summer $(201 \mathrm{~mm})$, followed by spring $(106 \mathrm{~mm})$, fall $(82 \mathrm{~mm})$, and winter $(52 \mathrm{~mm})$. Monthly historical precipitation fit within the range of variability of the stochastic precipitation at the basin scale. Maximum historical monthly PET ranged from $148 \mathrm{~mm}$ in July to $12 \mathrm{~mm}$ in January. Minimum historical values of PET in July and January were $87 \mathrm{~mm}$ and $2 \mathrm{~mm}$, respectively. Historical maximum PET was consistently lower than the maximum stochastic PET values. Minimum historical monthly PET was generally similar to and greater than the minimum stochastic PET values, except for the month of February in which one historical minimum PET value was less than the stochastic minimum PET value.

Annual moisture deficit was largest at Lake Darling Reservoir, followed by Rafferty Reservoir, and then Grant Devine Reservoir. The 50-percent nonexceedance probability of annual moisture deficit was $-150 \mathrm{~mm}$ at Lake Darling Reservoir, $-116 \mathrm{~mm}$ at Rafferty Reservoir, and $-75 \mathrm{~mm}$ at Grant Devine Reservoir. Summer had the highest moisture deficit, followed by fall, spring, and winter. Winter was the only season where nearly all quantile moisture deficit values were positive at the three reservoirs, except for the 5- and 10-percent quantiles at Lake Darling Reservoir. Moisture deficit is one indicator of the state of the climate in the basin. Moisture deficit is not solely responsible for the magnitude of runoff events, but it can be used as an indicator of wetter or drier periods relative to streamflow. Over long periods of time, conditions drier than the median moisture deficit may lead to a reduction in spring runoff and base streamflow.

Annual maximum monthly mean streamflow was determined for the Souris River below Rafferty Reservoir, Saskatchewan (Canadian streamgage 05NB036); Long Creek near Noonan (above Boundary Reservoir), North Dakota (USGS streamgage 05113600); Moose Mountain Creek near Oxbow, Saskatchewan (Canadian streamgage 05ND004); the Souris River near Sherwood, N. Dak. (USGS streamgage 05114000); the Des Lacs River at Foxholm, N. Dak. (USGS streamgage 05116500); and the Souris River above Minot, N. Dak. (USGS streamgage 05117500). From the annual maximum monthly mean streamflow data, the 50-, 25-, 10-, 5-, and 1-percent exceedance probabilities were calculated. Annual maximum monthly mean streamflows were highest for the Souris River below Rafferty Reservoir when 
comparing inflows to Rafferty, Boundary, and Grant Devine Reservoirs. Routed streamflow was highest for the Souris River above Minot.

Seasonal maximum monthly mean streamflows from summer and spring were plotted against their exceedance probability. The seasonal maximum monthly mean streamflows were calculated by retrieving the maximum monthly mean streamflow from a month within the spring and summer for each of the 10,000 trace years and assumed to be independent of one another. Summer maximum monthly mean streamflows were consistently lower than spring maximum monthly mean streamflows. However, when the seasonal maximum monthly mean streamflows are evaluated in contrast to annual maximum monthly mean streamflows separated by their seasonal occurrence, summer months of annual maximum monthly mean streamflows have a higher 50 -percent exceedance probability of streamflow compared to annual maximum monthly mean streamflows that occur in spring, seasonal maximum monthly mean streamflows that occur in spring, and seasonal maximum monthly mean streamflows that occur in summer. When annual maximum monthly mean streamflows in summer are compared to annual maximum monthly mean streamflows in spring, they are consistently higher in streamflow but occur in less than 4.2-percent of years. Evaluation of whether the annual maximum monthly mean streamflows that occur in summer can be described as a separate population from annual maximum monthly mean streamflows that occur in spring was outside the scope of this study, and the summer and spring annual maximum monthly mean streamflows were not tested for statistical differences in mean or variance. Further investigation of seasonal weather patterns that induce flooding could lead to a better understanding of the seasonal differences in flooding.

Long-term hydrologic drought was characterized by evaluating multiyear mean streamflow. A 1-year, 5-year, 10-year, and 20-year mean of monthly streamflow volume was calculated for each of the 100 traces at the Souris River below Rafferty Reservoir, Long Creek near Noonan (above Boundary Reservoir), Moose Mountain Creek below Oxbow, the Souris River near Sherwood, the Des Lacs River at Foxholm, and the Souris River above Minot. The 50-percent nonexceedance probability of stochastically generated streamflow for the 1-year mean streamflow at the Souris River near Sherwood was 2.42 cubic meters per second and increased to 4.73 cubic meters per second for the 20 -year mean. Shorter averaging periods have greater streamflow variability than longer periods and hence have a wider range of values. As the averaging period is extended to a longer period, the variability of mean streamflow decreases, and the more extreme streamflow volumes seen in shorter averaging periods cannot be sustained.

Stochastic streamflow time series were disaggregated spatially and temporally for use in a HEC-ResSim model. The disaggregation included spatial disaggregation from 15 subbasins identified in the stochastic unregulated water balance model to 26 subbasins that were developed based on points requiring streamflow input in the HEC-ResSim model. The spatially disaggregated stochastic streamflow traces were then disaggregated from 10-day streamflow traces with a length of 100 years to daily streamflow traces with dates between January 1, 3000, and December 31, 3099. The combination of monthly and daily stochastic streamflow data was used to select traces with qualities that could be used to test alternatives focused on water supply, summer flooding, and apportionment.

\section{References Cited}

Cleveland, W.S., 1979, Robust locally weighted regression and smoothing scatterplots: Journal of the American Statistical Association, v. 74, no. 368, p. 829-836. [Also available at https://doi.org/10.1080/01621459.1979.10481038.]

England, J.F., Jr., Cohn, T.A., Faber, B.A., Stedinger, J.R., Thomas, W.O., Jr., Veilleux, A.G., Kiang, J.E., and Mason, R.R., Jr., 2018, Guidelines for determining flood flow frequency-Bulletin 17C (ver. 1.1, May 2019): U.S. Geological Survey Techniques and Methods, book 4, chap. B5, 148 p. [Also available at https://doi.org/ 10.3133/tm4B5.]

Government of Canada, 2014, Water office: Government of Canada, accessed November 2014 at https://open.canada.ca/ data/en/dataset/450bb170-bf82-513f-af97-922f362cc3f8.

Gray, S.T., and McCabe, G.J., 2010, A combined water balance and tree ring approach to understanding the potential hydrologic effects of climate change in the central Rocky Mountain region: Water Resources Research, v. 46, no. 5, art. W05513, 13 p., accessed June 2018 at https://doi.org/ 10.1029/2008WR007650.

Halborg, C., and Muhammad, A., 2020, Souris River plan of study, HH10 - Forecasting assessment, SubtaskAssessment of a quantitative index of basin moisture conditions: Moose Jaw, Saskatchewan, Water Security Agency, Souris River Plan of Study, 80 p.

Haslinger, K., Koffler, D., Schöner, W., and Laaha, G., 2014, Exploring the link between meteorological drought and streamflow-Effects of climate-catchment interaction: Water Resources Research, v. 50, no. 3, p. 2468-2487. [Also available at https://doi.org/10.1002/2013WR015051.]

Helsel, D.R., Hirsch, R.M., Ryberg, K.R., Archfield, S.A., and Gilroy, E.J., 2020, Statistical methods in water resources: U.S. Geological Survey Techniques and Methods, book 4, chap. A3, 458 p. [Also available at https://doi.org/ 10.3133/tm4a3.] 
Hoerling, M., Eischeid, J., and Webb, R., 2013, Climate Assessment Report-Understanding and explaining climate extremes in the Missouri River Basin associated with the 2011 flooding: Boulder, Colo., National Oceanic and Atmospheric Administration, 34 p.

Hosking, J.R.M., 1990, L-moments-Analysis and estimation of distributions using linear combinations of order statistics: Journal of the Royal Statistical Society. Series B. Methodological, v. 52, no. 1, p. 105-124. [Also available at https://doi.org/10.1111/j.2517-6161.1990.tb01775.x.]

Huffman, R.L., Fangmeier, D.D., Elliot, W.J., Workman, S.R., and Schwab, G.O., 2011, Soil and water conservation engineering (6th ed.): St. Joseph, Mich., American Society of Agricultural Engineers, 523 p.

International Joint Commission, 2013, Plan of study-For the review of the operating plan contained in Annex A of the 1989 International Agreement between the Government of Canada and the Government of the United States of America: International Souris River Board, 213 p., accessed September 2020 at https://www.ijc.org/sites/default/files/ Souris\%20River\%20Basin\%20Plan\%20of\%20Study.pdf.

International Souris River Board, 2009, HydrologyInternational Souris River Board of the International Joint Commission: International Souris River Board Fact Sheet ISRB-2009B, 2 p., accessed July 8, 2020, at https://ijc.org/ sites/default/files/hydrology.pdf.

International Souris River Study Board, 2018, International Souris River Study Board work plan for the Souris River Basin: International Joint Commission, 58 p., accessed October 18, 2019, at https://www.ijc.org/sites/default/files/ 2019-01/work_plan_souris_river_public_final_0.pdf.

Kolars, K.A., Vecchia, A.V., and Galloway, J.M., 2019, Stochastic model for simulating Souris River Basin regulated streamflow upstream from Minot, North Dakota: U.S. Geological Survey Scientific Investigations Report 2018-5155, 36 p., accessed February 2019 at https://doi.org/ $10.3133 /$ sir20185155.

Kolars, K.A., Vecchia, A.V., and Ryberg, K.R., 2016, Stochastic model for simulating Souris River Basin precipitation, evapotranspiration, and natural streamflow: U.S. Geological Survey Scientific Investigations Report 2015-5185, 55 p., accessed May 2018 at https://doi.org/ $10.3133 / \operatorname{sir} 20155185$.

Lu, J., Sun, G., McNulty, S.G., and Amatya, D.M., 2005, A comparison of six potential evapotranspiration methods for regional use in the southeastern United States: Journal of the American Water Resources Association, v. 41, no. 3, p. 621-633. [Also available at https://doi.org/10.1111/ j.1752-1688.2005.tb03759.x.]
Mallakpour, I., and Villarini, G., 2015, The changing nature of flooding across the central United States: Nature Climate Change, v. 5, no. 3, p. 250-254. [Also available at https://doi.org/10.1038/nclimate2516.]

Neri, A., Villarini, G., Slater, L.J., and Napolitano, F., 2019, On the statistical attribution of the frequency of flood events across the U.S. Midwest: Advances in Water Resources, v. 127, p. 225-236. [Also available at https://doi.org/ 10.1016/j.advwatres.2019.03.019.]

Parzen, E., 1962, On estimation of a probability density function and mode: Annals of Mathematical Statistics, v. 33, no. 3, p. 1065-1076. [Also available at https://doi.org/ 10.1214/aoms/1177704472.]

R Core Team, 2017, R-A language and environment for statistical computing: Vienna, Austria, R Foundation for Statistical Computing.

Rosenblatt, M., 1956, Remarks on some nonparametric estimates of a density function: Annals of Mathematical Statistics, v. 27, no. 3, p. 832-837. [Also available at https://doi.org/10.1214/aoms/1177728190.]

Ryberg, K.R., 2015, Impact of climate variability on streamflow and water quality in the north central United States: Fargo, N. Dak., North Dakota State University, Ph.D. dissertation, $277 \mathrm{p}$.

Ryberg, K.R., Lin, W., and Vecchia, A.V., 2014, Impact of climate variability on runoff in the north-central United States: Journal of Hydrologic Engineering, v. 19, no. 1, p. 148-158. [Also available at https://doi.org/10.1061/(ASCE)HE.19435584.0000775.]

Ryberg, K.R., Vecchia, A.V., Akyüz, F.A., and Lin, W., 2016, Tree-ring-based estimates of long-term seasonal precipitation in the Souris River Region of Saskatchewan, North Dakota and Manitoba: Canadian Water Resources Journal, v. 41, no. 3, p. 412-428. [Also available at https://doi.org/ 10.1080/07011784.2016.1164627.]

Shapley, M.D., Johnson, W.C., Engstrom, D.R., and Osterkamp, W.R., 2005, Late-Holocene flooding and drought in the Northwestern Great Plains, USA, reconstructed from tree rings, lake sediments and ancient shorelines: The Holocene, v. 15, no. 1, p. 29-41. [Also available at https://doi.org/10.1191/0959683605hl781rp.]

United Nations, 1989, Agreement between the Government of the United States of America and the Government of Canada for water supply and flood control in the Souris River Basin: United Nations Treaty Series, v. 2203, I-39101, p. 3-22, accessed December 2020 at https://treati es.un.org/doc/Publication/UNTS/Volume\%202203/ v2203.pdf. 
U.S. Army Corps of Engineers, 2013a, HEC-ResSim Reservoir System Simulation user's manual (ver. 3.1, May 2013): Davis, Calif., U.S. Army Corps of Engineers, CPD-82, 556 p., accessed July 8, 2020, at https://www .hec.usace.army.mil/software/hec-ressim/documentation/ HEC-ResSim_31_UsersManual.pdf.

U.S. Army Corps of Engineers, 2013b, Regional reconstructed hydrology of the Souris River: St. Paul, Minnesota, U.S. Army Corps of Engineers, $158 \mathrm{p}$.

U.S. Army Corps of Engineers, 2020, HH1—Regional \& reconstructed hydrology extension: St. Paul, Minnesota, U.S. Army Corps of Engineers, 200 p.

U.S. Geological Survey, 2014, USGS water data for the Nation: U.S. Geological Survey National Water Information System database, accessed November 2014 at https://doi.org/10.5066/F7P55KJN.

U.S. Geological Survey, 2017, U.S. and Canada harmonized international sub-basins: U.S. Geological Survey web page, accessed March 21, 2019, at https://www.usgs.gov/ media/images/us-and-canadian-harmonized-internationalsub-basins.

Vecchia, A.V., 2008, Climate simulation and flood risk analysis for 2008-40 for Devils Lake, North Dakota: U.S. Geological Survey Scientific Investigations Report 2008-5011, 28 p. [Also available at https://doi.org/10.3133/ sir20085011.]
Venables, W.N., and Ripley, B.D., 2002, Modern applied statistics with S-Statistics and computing: Springer Publishing Company, Inc., 495 p. [Also available at https://doi.org/10.1007/978-0-387-21706-2.]

Vicente-Serrano, S.M., Beguería, S., and López-Moreno, J.I., 2010, A multiscalar drought index sensitive to global warming - The standardized precipitation evapotranspiration index: Journal of Climate, v. 23, no. 7, p. 1696-1718. [Also available at https://doi.org/10.1175/2009JCLI2909.1.]

Vining, K.C., Chase, K.J., and Loss, G.R., 2013, General weather conditions and precipitation contributing to the 2011 flooding in the Mississippi River and Red River of the North Basins, December 2010 through July 2011: U.S. Geological Survey Professional Paper 1798-B, 22 p., accessed May 2020 at https://doi.org/10.3133/pp1798B.

York, B., Gregory, A., and Galloway, J., 2021, Historical and stochastically generated climate and streamflow data for the Souris River Basin, United States and Canada: U.S. Geological Survey data release, https://doi.org/10.5066/ P93AOWFL.

Zhu, Y., Wang, W., Singh, V.P., and Liu, Y., 2016, Combined use of meteorological drought indices at multi-time scales for improving hydrological drought detection: The Science of the Total Environment, v. 571, p. 1058-1068. [Also available at https://doi.org/10.1016/j.scitotenv.2016.07.096.] 
For more information about this publication, contact: Director, USGS Dakota Water Science Center

821 East Interstate Avenue, Bismarck, ND 58503

1608 Mountain View Road, Rapid City, SD 57702

605-394-3200

For additional information, visit: https://www.usgs.gov/centers/ dakota-water

Publishing support provided by the

Rolla Publishing Service Center 
